IZA DP No. 4351

Reputation and Credit Market Formation: How Relational Incentives and Legal

Contract Enforcement Interact

Ernst Fehr

Christian Zehnder

August 2009 


\title{
Reputation and Credit Market Formation: How Relational Incentives and Legal Contract Enforcement Interact
}

\author{
Ernst Fehr \\ University of Zurich \\ and IZA \\ Christian Zehnder \\ University of Lausanne \\ Discussion Paper No. 4351 \\ August 2009 \\ IZA \\ P.O. Box 7240 \\ 53072 Bonn \\ Germany \\ Phone: +49-228-3894-0 \\ Fax: +49-228-3894-180 \\ E-mail: iza@iza.org
}

Any opinions expressed here are those of the author(s) and not those of IZA. Research published in this series may include views on policy, but the institute itself takes no institutional policy positions.

The Institute for the Study of Labor (IZA) in Bonn is a local and virtual international research center and a place of communication between science, politics and business. IZA is an independent nonprofit organization supported by Deutsche Post Foundation. The center is associated with the University of Bonn and offers a stimulating research environment through its international network, workshops and conferences, data service, project support, research visits and doctoral program. IZA engages in (i) original and internationally competitive research in all fields of labor economics, (ii) development of policy concepts, and (iii) dissemination of research results and concepts to the interested public.

IZA Discussion Papers often represent preliminary work and are circulated to encourage discussion. Citation of such a paper should account for its provisional character. A revised version may be available directly from the author. 


\section{ABSTRACT \\ Reputation and Credit Market Formation: How Relational Incentives and Legal Contract Enforcement Interact ${ }^{*}$}

The evidence suggests that relational contracting and legal rules play an important role in credit markets but on the basis of the prevailing field data it is difficult to pin down their causal impact. Here we show experimentally that relational incentives are a powerful causal determinant for the existence and performance of credit markets. In fact, in the absence of legal enforcement and reputation formation opportunities the credit market breaks down almost completely while if reputation formation is possible a stable credit market emerges even in the absence of legal enforcement of debt repayment. Introducing legal enforcement of repayments causes a further significant increase in credit market trading but has only a surprisingly small impact on overall efficiency. The reason is that legal enforcement of debt repayments weakens relational incentives and exacerbates another moral hazard problem in credit markets - the choice of inefficient high-risk projects.

JEL Classification: C91, G21, G28, L14

Keywords: credit markets, relationship lending, reputation formation, legal enforcement

Corresponding author:

Ernst Fehr

Institut für Empirische Wirtschaftsforschung

Universität Zürich

Blümlisalpstrasse 10

$\mathrm{CH}-8006$ Zürich

Switzerland

E-mail: efehr@iew.uzh.ch

\footnotetext{
${ }^{*}$ We would like to acknowledge financial support from the Research Priority Program of the University of Zurich on the "Foundations of Human Social Behavior" and the National Center of Competence in Research on "Financial Valuation and Risk Management" (NCCR Finrisk). The National Centers in Research are managed by the Swiss National Science Foundation on behalf of the federal authorities.
} 


\section{Introduction}

Around the world credit markets are a major source of financing business projects (Rajan and Zingales 1995, Djankov, McLiesh and Shleifer 2007) and it is well known that adverse selection and moral hazard (Jaffee and Russel 1976, Stiglitz and Weiss 1981) are major obstacles for the development of these markets. Recent work has indicated the importance of legal rules and information sharing institutions for the functioning of credit markets (Pagano and Japelli 1993, La Porta and Lopez de-Silanes 1997, La Porta et al. 1998, Japelli and Pagano 2002, Lerner and Schoar 2005, Jappelli, Pagano and Bianco 2005; Djankov, McLiesh and Shleifer 2007), while a different literature has stressed the role of relationship banking and individual reputation mechanisms (Petersen and Rajan 1994, Berger and Udell 1995, Boot 2000, Boot and Thakor 2000, Ongena and Smith 2000 and 2001, Degryse and Ongena 2005). However, although reputation mechanisms are relatively well understood at the theoretical level (Sobel 1985, Fudenberg and Maskin 1986), it is very difficult to show with field data that individual reputation formation is causally involved in relationship banking and the endogenous enforcement of credit repayments. Furthermore, both "institutions" and "relations" almost always simultaneously affect credit market behavior and very little is known about how these enforcement mechanisms interact. It is not known whether "institutions" and "relations" complement each other or whether legal enforcement "crowds out" reputational enforcement mechanisms.

In this paper we, therefore, use the methods of experimental economics to examine how reputation formation opportunities causally influence contract enforcement and market efficiency in credit markets. ${ }^{4}$ In addition, our experiment allows us to study the causal impact of legal third party enforcement of credit contracts and the interaction between legal enforcement and the endogenous enforcement of contracts in long-term credit relations. For this purpose, we conduct experiments in a laboratory environment in which two potential sources of moral hazard coexist. The first source of moral hazard is the presence of asymmetric information about project characteristics. Since lenders do not observe the project choice, they cannot prevent borrowers from choosing inefficient high-risk projects. This reflects the natural information asymmetry in credit markets: borrowers typically have more and better information about their investment opportunities than lenders. The second source for moral hazard is the absence of legal enforcement of debt repayment. This implies that

\footnotetext{
${ }^{4}$ Laboratory experiments have a long tradition in the study of financial markets. For example, already Burell (1951) used an experiment to investigate investment behavior in a controlled way. In the last two decades the experimental literature has importantly contributed to a better understanding of price determination in security and asset markets. For examples see, Ang and Schwarz (1985), Copeland and Friedman (1987, 1991), O'Brien and Srivastava (1991), Schnitzlein (1996), Lamoureux and Schnitzlein (1997), Gneezy et al. (2003), Kluger and Wyatt (2004), Haigh and List (2005), and Haruvy and Noussair (2006).
} 
borrowers may escape the repayment of their loans even in case of a successfully realized project. A lack of enforceable repayments can be interpreted as a stylized representation of the institutional weaknesses observed in many developing and emerging credit markets but recent evidence (Djankov et al. 2008) suggests that even in many advanced Western countries the enforcement of debt repayment is surprisingly inefficient.

The enhanced control provided by the experimental method enables us to isolate the pure effect of individual reputation formation in endogenously built long-term relationships on the solution of the double moral hazard problem. We compare a treatment in which we rule out any information about the identity of trading partners (so that no reputation can be formed) with a treatment in which individual borrowers can acquire a reputation. A main reason for the conduct of our experiments is that it is rarely possible to find field data in which information about the traders' identity varies exogenously. Therefore, field data do typically not allow for the clean identification of the extent to which reputational incentives are causally involved in solving the moral hazard problems inherent in credit markets.

Once we have identified the pure reputation effect on credit market functioning, we are in a position to study the interaction between legal enforcement of credit repayment and reputational incentives. We do this by implementing third party enforcement of credit repayments under conditions of limited liability and wealth constraints for the borrowers. In particular, the third party can force the borrower to repay his loan if the borrower's project turns out to be successful but if the project fails no repayment can be enforced because borrowers have no wealth that could be taken away from them. While third party enforcement resolves the credit repayment problem, the borrowers still have the possibility to choose inefficient high risk projects. This may be attractive because limited liability implies that they can shift part of the project risk on the lenders. We believe that this set-up characterizes the situation in many advanced Western economies in which borrowers' cannot easily escape their legal obligations to repay their debt if they have resources that can be taken away from them but once their projects fail and they lack sufficient wealth, the legal system can do little to ensure debt repayment.

Our results indicate that individual reputation formation in long-term credit relations has a powerful impact on the enforcement of credit contracts. In the absence of third party enforcement, the lack of reputation formation opportunities leads to a breakdown in credit market trading. If borrowers can acquire a reputation, however, stable credit markets emerge in which roughly $80 \%$ of all feasible trades take place. If borrowers' identities are known the lenders condition future credit offers on the borrower's current repayment behavior such that the borrowers face incentives to repay their debt and to choose the efficient low-risk project. Thus, reputation formation in endogenously formed long-term credit relations strongly 
alleviates the double moral hazard problem in our credit market although it does not solve it completely.

The introduction of third party enforcement into a market in which reputation formation plays a key role in contract enforcement leads to a further significant increase in trading activity. Interestingly, third party enforcement does not reduce the prevalence of multi-period credit interactions between pairs of borrowers and lenders. However, the efficiency gains from third party enforcement are surprisingly small and insignificant because it exacerbates the project choice problem. In fact, without third party enforcement the efficient project is chosen in $90 \%$ of the cases while in the presence of third party enforcement this occurs only in roughly $50 \%$ of the cases.

The likely reason for the decrease in efficient projects is twofold. First, in the presence of legal enforcement of repayments, borrowers face stronger short-term incentives to choose the inefficient project. Due to limited liability and wealth constraints borrowers who are forced to repay in case of project success can increase their expected short-term-profit by choosing the risky project because the increased risk is partly borne by the lender. This effect is especially strong because legal enforcement of debt repayment also strengthens the lenders' position in the market and induces them to ask for higher repayments. Second, we find that the conditioning of future credit on current repayment is weaker under third party enforcement, i.e., incumbent borrowers who repay their credit experience a lower increase in the probability of receiving future credit. Together these two factors imply that third party enforcement weakens the incentives for efficient project choices in important ways which leads to a lower prevalence of efficient projects.

Our study is related to the literature on relationship banking that examines the economic role and the determinants of long-term relations between borrowers and lenders (Petersen and Rajan 1994, Berger and Udell 1995, Boot 2000, Boot and Thakor 2000, Ongena and Smith 2000 and 2001, Degryse and Ongena 2005). This literature provides convincing evidence for the prevalence and the potentially value-enhancing role of long-term relationships in credit markets. In principle, long-term relations could be valuable because the lender has access to the borrower's books and thus receives more direct insights into the borrower's economic activities which enable her to better assess the risks involved in providing credit. Alternatively, long-term relations may be a consequence of lenders' contingent renewal of future credit contracts: if lenders condition access to future credit on the repayment of current debt the borrowers face incentives to repay their debt. Thus, here the existence of long-term credit relations merely results from the successful repayment of credit which is itself a result of the incentives provided by contingent contract renewal. 
It is hard, if not impossible, to disentangle these forces in existing field data while our experiment enables us to isolate them in a clean way. In particular, in the experiments the lender never had access to information about the borrower's past or current project choices. Therefore, we can rule out that long-term relations are associated with better information access. Instead, long-term relations are a result of lenders' contingent renewal policy, the associated incentives for credit repayment and efficient project choices and, therefore, they enhance the gains from trade in our credit markets.

Our study is also related to the literature on the role of legal enforcement institutions in credit markets (e.g., La Porta and Lopez de-Silanes 1997, La Porta et al. 1998, Djankov, McLiesh and Shleifer 2007). This literature documents that the role of private credit in a market economy increases with creditor protection, indicating an important role of legal enforcement institutions. The interpretation of correlational data is however not easy because causation can go in both directions. Creditor protection may cause flourishing credit markets but it is also possible that credit markets emerge through endogenous (reputational) enforcement mechanisms and that higher credit market participation causes political pressures that strengthen creditors' rights. In view of the uncertainty whether reverse causation is partly behind the observed link between creditor protection and the economic role of private credit in cross country comparisons, an experimental study of the role of legal enforcement of credit repayment is valuable because in the experiment we can rule out reverse causation with certainty. Thus, we can be completely sure that the increased level of trading activity under legal enforcement is caused by the enforcement institution.

In addition, the exogenous introduction of legal enforcement in an environment with endogenous enforcement of credit contracts enables us to study the causal impact of legal on endogenous enforcement. To the best of our knowledge we are the first ones who empirically address the important question of how endogenous (reputation based) incentives interact with exogenous (legal) incentives. Our finding that legal enforcement weakens reputational incentives and increases the frequency of inefficient project choices indicates that legal and endogenous enforcement mechanisms may have unexpected interactions which renders the further study of such interaction effects worthwhile. ${ }^{5}$

Since we investigate the disciplining power of relationships our work is also related to the literature on reputation formation in repeated games (Kreps et al. 1982, Sobel 1985,

\footnotetext{
${ }^{5}$ Baker, Gibbons and Murphy (1994) provide a theoretical analysis between explicit incentives and relational incentives in a firm-worker relationship. They show that better explicit incentives may weaken relational incentives because a better explicit incentive reduces the firm's ability to commit to bonus payments that incentivize the workers' effort. In our setting, the crowding out of relational incentives through legal enforcement of debt repayment is based on a different mechanism - the lender's weaker conditioning of future credit on current repayment. An examination of the interaction between informal and formal enforcement in partnerships is provided by Sobel (2006).
} 
Fudenberg and Maskin 1986). This literature shows that cooperation can be sustained as an equilibrium in situations involving repeated play. However, the theory also reveals (e.g. Fudenberg and Maskin 1986) that there is in general a plethora of equilibria some of which involve full cooperation while others involve complete defection by all players. For this reason, theory alone provides little guidance regarding the likely consequences of reputation formation for the functioning of credit markets. Recent experimental work provides evidence that reputation formation can indeed mitigate moral hazard problems. For example, Brown et al. (2004) find that individual reputation effects have efficiency enhancing effects in endogenously formed employment relationships and Brown and Zehnder (2007) show that information sharing among lenders provides strong incentive for borrowers to repay their debt. However, our experiment differs from these experiments in important aspects. First, the former experiments make reputation formation easy because they use deterministic setups in which the principal can directly observe the agent's action whereas our set-up captures a key characteristic of credit markets - asymmetric information between borrowers and lenders and uncertainty about project success. For this reason, previous experiments also cannot study the simultaneous occurrence and interaction of the two key moral hazard problems in credit markets - the repayment problem and the project choice problem. Second, previous experimental studies also do not examine the interaction between legal enforcement and relation incentives.

In the presence of stochastic project success and asymmetric information it is far from obvious that repeated interactions are capable of sustaining cooperation between borrowers and lenders. The reason is that the lenders cannot observe the borrower's project choice nor can they observe whether the project has been successful; they can only observe whether the borrower repays his credit. If a borrower does not repay his credit in the market without legal enforcement the lender does not know whether the borrower is unable to repay his credit (because the project failed) or unwilling to repay his debt. Even an honest borrower who intends to repay his debt in case of project success and who chooses the efficient low risk project may face a project failure so that he cannot repay his debt. The lender never has certainty about whether he faced an opportunistic borrower who did not intend to repay his debt even in case of project success or whether the borrower had just bad luck. The double moral hazard problem in our credit market makes it thus very difficult to acquire a reputation as a good borrower, which makes the powerful effect of individual reputation formation opportunities on contract enforcement all the more remarkable.

The remainder of the paper is structured as follows: in Section II we present the details of our experimental design and the applied procedures. Section III contains our predictions and hypotheses. In Section IV we present our results and Section V concludes the paper. 


\section{Experimental Design}

We implement an experimental credit market, in which two sources for moral hazard coexist. Since the lender cannot observe the borrower's project choice, borrowers may choose inefficient high risk projects. In addition, the absence of legal enforcement of repayments implies that borrowers may withhold their repayment even if they have successfully realized their project. In a first step, we investigate in how far reputational incentives in endogenously formed relationships succeed in improving credit market efficiency when both sources for moral hazard are present. In a second step, we introduce legal enforcement of credit repayments and therewith eliminate one of the two potential moral hazard problems. We study how this interacts with the reputational incentives in relationships and examine the overall impact of the legal enforceability of repayments on credit market efficiency.

We implement three treatment conditions in our experiment. The first condition is a baseline treatment which is designed to show that our market suffers from severe moral hazard problems if neither relational nor legal enforceability of contracts is available. In this condition credit repayments of borrowers are not legally enforceable and lenders are confronted with anonymous borrowers in every period. The borrowers' anonymity rules out reputational incentives because it makes the formation of long-term relations between lenders and borrowers infeasible. Experimentally, anonymity is guaranteed by reassigning a new identification (ID) number to each participant at the beginning of every period. Essentially, this treatment implements a series of one-shot credit markets and, therefore, we call it the oneshot condition (OC).

The second condition is identical to the OC except for the fact that we now allow for the endogenous formation of bilateral relationships. To this end, we assign a fixed ID number to every participant. This ID number remains constant over all periods of the session. In this condition, a lender can repeatedly offer credit to the same borrower (i.e., the same ID number) and, if the borrower accepts these offers, a long-term relationship is established. We call this condition the relationship condition (RC). A comparison of the $\mathrm{RC}$ and the $\mathrm{OC}$ enables us to study the impact of reputation formation in endogenously built relationships on credit market efficiency.

To examine how legal enforcement of credit repayments affects credit market efficiency and how it interacts with relational incentives, we conduct another treatment condition - the third party condition (TPC). The TPC is identical to the RC except that we assume that the borrower is subject to a legal bankruptcy procedure which allows liquidating the borrower whenever the repayment does not meet the contractually defined amount. Liquidation is assumed to be sufficiently costly for the borrower such that it is always in the 
interest of the borrowers to repay whatever their project returns allow them to repay, up to the contractually agreed upon repayment. In order to simplify the experiment we do not explicitly implement the liquidation procedure and the associated repayment choice of the borrower. Instead, the computer automatically imposes the borrower's dominant strategy.

Note that we deliberately implemented a third party condition that solves the moral hazard problem with regard to the repayment of project returns in case of successful projects while it does not automatically solve the second moral hazard problem - the project choice problem. Thus, our third party condition is based on the assumption that there is still sufficient asymmetric information between the third party and the borrower such that the third party cannot enforce contracts that condition on project choice or project returns. However, as in the RC, in the TPC it is of course possible to solve the project choice problem with relational incentives and an interesting question is how relational incentives solve this problem when the repayment problem is solved.

This design choice can also be viewed from the following perspective. Depending on the details of legal enforcement procedures they can affect credit market efficiency in two ways. First, they can provide direct incentives for the borrowers to meet their contractual obligations. Second, they can change the informational environment such that the parties are able to write more sophisticated explicit contracts by conditioning on a larger set of events, thus providing additional incentives for the borrowers. ${ }^{6}$ Because it is desirable to disentangle the effects of these two aspects of legal enforcement procedures we concentrate in this paper on the first one - the direct incentive effect. For this reason, we rule out that the parties can write a larger set of contracts under legal enforcement.

In all three treatments the interaction takes place via computer terminals and the traders don't know other traders' personal identities. The traders only know others' identification numbers. For example, lender no. 7 (L7) knows that he is trading with borrower no. 5 (B5) in a particular period. In the RC and the TPC B5 denotes the same borrower (and L7 denotes the same lender) throughout the experiment while in the OC treatment B5 (L7) is randomly assigned to a different borrower (lender) in each period. This method enables us to remove confounding effects of home-grown reputations associated with subjects' personal identities from the experiment and to study the causal impact of reputation formation in the credit market in a clean way.

In all three treatments we implement the same credit market which lasts for 20 identical periods. The market consists of 17 participants. Seven participants are in the role of lenders, the other ten are borrowers. The roles are randomly assigned to the subjects at the

\footnotetext{
${ }^{6}$ For a discussion, see, for example, Diamond (1989, pp. 832-833). For an interesting study of the second aspect see Lerner and Schoar (2005).
} 
beginning of a session and remain fixed over all periods. In every period each borrower has two projects available: project $\mathrm{A}$ and project $\mathrm{B}(p \in\{\mathrm{A}, \mathrm{B}\})$. We assume that there are capacity constraints such that each borrower can at most realize one of the two projects. Both projects require an investment $i=32$ capital units to be set up. Project $\mathrm{A}$ is an efficient lowrisk project with a high expected return but a moderate return in case of project success $(\mathrm{R}=$ $\left.R^{A}\right)$. Project B is an inefficient high-risk project with a lower expected return than project $\mathrm{A}$ $(\mathrm{E}[R \mid p=\mathrm{A}]>\mathrm{E}[R \mid p=\mathrm{B}])$ but a higher return in case of project success $\left(R^{B}>R^{A}\right)$. $\mathrm{A}$ project failure always results in a project return of zero $(R=0)$. In Table I the characteristics of the two projects are shown in detail.

Borrowers do not have any endowments (equity) and they are not able to carry excess returns into future periods. ${ }^{7}$ This implies that borrowers need external funding to realize a project. If a borrower does not conclude a credit contract, he has access to an alternative project, which does not require external funding and yields a period payoff of $b=10$.

Each lender is endowed with $k=32$ capital units at the beginning of every period. A lender has two opportunities to make use of his endowment. He can either invest his whole endowment in an endowment-storing technology which yields a payoff of 32 or he can use his 32 capital units to extend credit to a borrower. A period consists of two stages. The first stage of each period is a continuous one-sided auction, in which lenders have the opportunity to make credit offers to borrowers. A credit offer contains three pieces of information: the desired project $\left(p^{d} \in\{\mathrm{A}, \mathrm{B}\}\right)$, the desired repayment in case of project success $\left(r^{d}\right)$ and whether the offer is private or public. Public credit offers can be seen and accepted by all borrowers. Private credit offers are addressed to a specific borrower and cannot be seen or accepted by the other borrowers. Public offers are also displayed on the other lenders' screens. A lender can make as many public and private offers as he wants. However, as his endowment consists of 32 capital units, it suffices to finance one project only. Thus, as soon as a borrower accepts one of the posted offers of a lender a contract is concluded and - at the same time - all other outstanding offers of this lender disappear from the market and can no longer be accepted.

In the second stage of each period all borrowers, who have accepted a credit offer, choose whether they want to invest the obtained capital in project A or project B. As soon as all borrowers have made their investment decisions a random device determines whether a project is a success or a failure. ${ }^{8}$ In case of a project failure, the project's return is zero and the

\footnotetext{
7 This is a standard assumption in the theoretical literature focusing on reputation effects (see e.g. Diamond (1989) or Vercammen (1995)). It implies that the borrowers' wealth constraints remain constant over time such that dynamic effects do not change the borrowers' incentives.

${ }^{8}$ To avoid any suspicions concerning manipulations in computerized random devices the project success is always determined by publicly throwing a ten-sided dice. Project successes are independent across contracts.
} 
borrower cannot make a repayment to the lender $(r=0)$. If the project turns out to be successful, the borrower is able the make repayments up to the level of the project return $(r \leq$ $R^{p}$ ). The project choice and the realized return are private information to the borrower. The only information observable to the lender is the repayment decision of the borrower. Thus, in the OC and the RC, where debt repayments are not third party enforceable, the lender is not only unable to find out which project has been chosen, but in case of no repayment he does also not know whether a borrower has suffered from a project failure or has simply kept the whole project return to himself. In the TPC, where borrowers are exogenously forced to meet the repayment desired by the lender whenever possible $\left(r=\min \left(R, r^{d}\right)\right)$, the fact that the borrower repays reveals that his project was successful, but lenders are not informed about the borrower's project choice.

At the end of the period the payoffs of the market participants are calculated:

Profit lender $\quad=$ Repayment $(r), \quad$ if the lender extends credit $=32(k), \quad$ if the lender uses endowment storing

Profit borrower $=$ Project return $(R)-$ Repayment $(r)$, if the borrower gets credit $=10(b), \quad$ if the alternative project is realized

Payoff functions, the number of lenders and borrowers and the number of trading periods are common knowledge.

To make sure that all participants fully understood the decision process and the payment structure of the game, each participant had to read a detailed set of instructions before a session was started. After reading the instructions participants had to answer questions that enabled us to check their comprehension of the rules of the experiment (payoff computations, information conditions, trading rules, etc). ${ }^{9}$ We never started a session before all subjects had correctly answered all comprehension questions. Additionally each experiment contained two practice periods in order to make the participants familiar with the bidding procedures. In both practice periods subjects only went through the first stage of the period (auction with credit offers). There were no project and repayment choices and the practice periods did not affect the participants' payoffs.

All experimental subjects were volunteers. Each participant could only participate in one session (i.e., each subject experienced only one of the treatment conditions). All participants were students of the University of Zurich or the Swiss Federal Institute of Technology in Zurich (ETH). We used the recruitment system ORSEE (Greiner 2004).

This is achieved by independently drawing "winning-numbers" for each borrower. The "winning-numbers" are displayed in form of a table on the borrowers' screens before the dice is thrown.

${ }^{9}$ Instructions and control questions are available on request. 
In total we conducted 15 experimental sessions, five in every treatment condition. We had 17 subjects in each session, which makes a total of 255 participants in the experiment. The computerized experiment was programmed and conducted with the experimental software z-Tree (Fischbacher 2007). A session lasted approximately ninety minutes and subjects earned on average 59 Swiss Francs ( 50 US-Dollars (January 2008)).

\section{Behavioral Predictions}

In this section we present the predictions for our experiment. Section III.A contains a game theoretic analysis of our treatment conditions for the case of rational, profit-maximizing market participants. Under this assumption no credit market can exist in the OC and the RC, while in the TPC only a very inefficient credit market emerges in which only high-risk projects are realized. However, there is a large empirical literature suggesting that the assumption that all people are exclusively interested in the maximization of their own material payoff is empirically wrong (Fehr and Gächter 2000, Camerer 2003, Sobel 2005). Instead, this literature indicates that a fraction of people also care about social motives and behave in a trustworthy manner. In our context trustworthy behavior means that a person voluntarily makes credit repayments out of social concerns even if there is a strong monetary incentive not to repay. In Section III.B we discuss how the existence of such trustworthy borrowers influences credit market trading in our three treatment conditions. We confine the discussion of the effects of these traders to the intuitive level in this section. However, we corroborate our arguments with a theoretical foundation in the Appendix, where we formally show the existence of reputation equilibria for simplified versions of our experimental games in the RC and the TPC.

\section{A. Predictions with Rational and Selfish Agents}

In this section we derive a benchmark prediction based on the assumption that all traders are rational maximizers of expected profits. Due the finite time horizon of the experiment a simple backward induction argument predicts hat in the $\mathrm{OC}$ and the RC no credit market transactions will take place. Since there is no institution that enforces debt repayment, the one-shot nature of the OC implies that borrowers never repay. Lenders anticipate this behavior and are therefore not willing to offer credit. The possibility to engage in repeated interactions with the same trading partner in the $\mathrm{RC}$ does not change this prediction. It is important to emphasize that we made it common knowledge that the experiment lasts exactly 20 periods. Thus, in the final period all participants know that they face the same incentives as in a one-shot encounter. Accordingly, the prediction is that lenders are not willing to extend credit in the final period. However, because rational borrowers anticipate that they will not be 
offered credit in the final period, the lenders cannot discipline the borrowers in the next to last period (lenders cannot credibly offer future benefits for good borrower behavior). As a consequence, borrowers will not repay credit in the next to last period, implying that no trade takes place in this period either. The same argument can now be applied to all periods, implying that no credit market will exist in any of the periods.

In the TPC the existence of third party enforcement of repayments forces borrowers to repay as much of the contractually agreed upon repayment as the project's return allows. However, the incentive structure in the stage game is such that - for all credit terms a lender is willing to offer - the borrower's best response is always project B. To understand this, remember that lenders can always make a safe profit of 32 by investing in the endowmentstoring technology. The expected profit of a lender offering credit to a borrower who choses project $p$ is given by $\mathrm{E}\left[\pi_{L}\right]=w^{p} r^{d}$. Thus, even in the best case, in which a lender is certain that his borrower chooses the efficient project $\mathrm{A}$ (which has a success probability of $w^{A}=0.8$ ), the lender is never prepared to make a credit offer with a lower desired repayment than $r^{d}=40$. The expected profit of a borrower in the TPC is only dependent on his project choice

$p \in\{\mathrm{A}, \mathrm{B}\}$ and can be written as follows: $\mathrm{E}\left[\pi_{\mathrm{B}}\right]=w^{p}\left(R^{p}-r^{d}\right)$. Inserting the corresponding numbers for projects $\mathrm{A}$ and $\mathrm{B}$ yields that borrowers prefer project $\mathrm{B}$ for all desired repayments $r^{d} \geq 40$. Thus, all credit offers a profit-maximizing lender is ever willing to make provide monetary incentives for borrowers to choose project B.

Due to the finite number of periods in the experiment, backward induction ensures, that the borrowers choose project B in all periods. Since lenders are on the short side of the market and anticipate the borrowers' behavior, they will enter the credit market and always ask for the highest repayment a borrower is just willing to accept. The borrowers' highest accepted repayment is $r^{d}=166$ because by accepting a repayment of 166 and choosing project $\mathrm{B}$ a borrower is slightly better off than if he takes his outside-option $b=10: \mathrm{E}\left[\pi_{\mathrm{B}}\right]=0.3(200-$ $166)=10.2>10$. Contracts with desired repayments above 166 are rejected by the borrowers. Thus, in the TPC the assumption that all market participants are rational expected profitmaximizers implies that a credit market is formed, in which all available trades are realized. However, since borrowers only choose inefficient high-risk projects, the credit market in the TPC still suffers from the negative consequences of moral hazard.

\section{B. Predictions with Heterogeneous Borrowers}

In the last two decades a large empirical literature emerged which suggests that not all people's behavior is exclusively driven by material self interest (for an overview see, e.g., Fehr and Gächter 2000, Camerer 2003, Sobel 2005). Instead, a non-negligible share of the population also exhibits social preferences, i.e., a concern for fair treatment, fair outcomes 
and reciprocity. In the meantime, there are even results from experiments with nationally representative samples (Bellemare and Kröger 2007; Bellemare, Kröger and Van Soest 2008; Fehr et al. 2002) which indicate the relevance of social preferences for a non-negligible share of people. For individuals with social preferences economic self-interest is still an important argument in the utility function but, in addition, the person also shows a concern for fairness (Fehr and Schmidt 1999, Bolton and Ockenfels 2000) or reciprocity (Rabin 1993, Dufwenberg and Kirchsteiger 2004, Falk and Fischbacher 2006) and sometimes even for efficiency (Charness and Rabin 2002).

In our context this means that - in addition to selfish profit-maximizers - there may also be borrowers who are prepared to honor the contract if a lender makes a credit offer that they perceive as fair, i.e., if the borrower is offered a fair share of the project returns. In the following we call such borrowers "trustworthy" borrowers. ${ }^{10}$ It is obvious, that if almost all borrowers are trustworthy even the one-shot credit contracts in the OC may be become attractive to lenders. The existing empirical evidence (see e.g. Fehr and Gächter 2000, Camerer 2003) suggests that our setting makes it rather unlikely that social preferences alone ensure a functioning credit market. ${ }^{11}$ But, whether the actual fraction of trustworthy borrowers is sufficient to sustain credit market trading in the OC is, of course, an empirical question.

However, below we argue that reputation formation opportunities may enable the formation of a stable credit market in the RC even if there are insufficiently many trustworthy borrowers to make trading profitable for the lenders in the OC. In other words, even if credit market trading is absent in the $\mathrm{OC}$, the existence of trustworthy types may generate reputational incentives which motivate selfish borrowers to repay and make a stable credit market possible in the RC. Thus, the possibility for repeated interactions may greatly enhance the impact of the presence of trustworthy types, an insight that echoes the theoretical analysis in Kreps et al. (1982).

In the following we will explain why the existence of reputation formation opportunities makes the situation in the RC very different from the situation in the OC. We provide the basic intuition why reputational incentives may imply that not only trustworthy borrowers, but also selfish borrowers will choose the efficient project A and repay their debt in the RC. The key feature that distinguishes the RC from the OC is that lenders can offer credit to the same borrowers in future periods. Because of the finite time horizon a lender is

\footnotetext{
${ }^{10}$ To keep the analysis tractable we assume in this section that there is only heterogeneity with regard to social preferences among the borrowers. This is makes sense because there is no moral hazard problem on the lenders' side and we focus exclusively on how the borrowers' moral hazard problems can be solved.

${ }^{11}$ The existing evidence indicates that the share of people with social preferences is typically below $60 \%$, and sometimes even much lower. If we take the upper bound and assume that $60 \%$ of borrowers are trustworthy, all these borrowers would need to be willing to choose the efficient project and make a repayment of at least 67 whenever their project turns out to be successful. Given the previous evidence this seems rather unrealistic.
} 
never willing to renew a contract with a borrower who is known to be selfish (see the backward induction argument in Section III.A). A borrower can therefore only benefit from a contract renewal, if his current lender has a sufficiently strong belief that her is trustworthy. Since lenders do not observe project returns, the only basis for assessing a borrower's trustworthiness is his repayment behavior. Lenders know that trustworthy borrowers are willing to repay whenever possible, as long as they are offered fair contract terms. If lenders offer fair contracts and condition the renewal of their contract in the next period on the current repayment, a selfish borrower may, therefore, have an incentive to choose the efficient project and repay his debt after project success in the non-final periods. ${ }^{12}$ The rationale behind this behavior is that it increases his chances to get another attractive credit offer from his current lender in the next period.

Note that while the lenders' contingent renewals of credit offers provide an incentive for selfish borrowers to mimic the trustworthy borrowers' repayment behavior, no perfect pooling equilibrium in which both types of borrowers repay with certainty after project success exists. The reason is the following: If all borrowers choose project $\mathrm{A}$ and repay with probability one after project success, the repayment does not contain any information on the borrower's type and accordingly a zero-repayment would always be attributed to a project failure. As a consequence, lenders would have no reason to condition their offers on the borrowers past behavior and defaulting would not result in lower future benefits for borrowers. But the absence of a difference between future payoffs after repaying and defaulting implies that selfish borrowers would never have any incentives to repay their debt. Thus, in equilibrium, selfish borrowers who successfully realize their project only repay with a positive probability while trustworthy borrowers with a successful project repay with certainty (see also Proposition A2 in the Appendix).

Since selfish borrowers repay with a lower probability than trustworthy borrowers, lenders can update their belief about a borrower's type based on his repayments over time. Lenders only extend credit to a borrower, if they have a sufficiently strong belief that he is trustworthy. Because trustworthy borrowers repay more often, they are more likely to remain creditworthy over time. This implies that within the sample of borrowers who still receive credit offers, the fraction of trustworthy borrowers increases over time and lenders adjust their beliefs accordingly. Since borrowers with a very good repayment history are likely to be

\footnotetext{
${ }^{12}$ Intuitively, one might think that choosing project B instead of project A could be attractive for a selfish borrower who plans to repay in case of project success. The reason is that project B generates higher expected returns in the current period if the borrower plans to repay (see Section III.A for details). However, choosing project $\mathrm{B}$ also decreases the probability of a project success and therefore the probability of getting the more attractive future returns associated with repayment. It is straightforward to show that the decrease in expected future returns always outweighs the increase in current expected returns. Thus, whenever reputational incentives motivate a borrower to repay, he has also incentives to choose project A (for details see the proof of Proposition A2 in the Appendix).
} 
trustworthy, they may even receive credit in the final period, where the lack of reputational incentives implies that selfish borrowers default with certainty.

The mechanism described above is based on the existence of some trustworthy borrowers and the lenders' contingent renewal policy which disciplines the selfish borrowers in the non-final periods and makes it profitable for the lenders to offer credit. It is important to emphasize that this behavior can be sustained in an equilibrium (see Proposition A2 in the Appendix for details). However, the described equilibrium is only one among many different equilibria. Therefore, theory does not provide a unique prediction. This is a generic feature of repeated games in which reputation matters and makes it all the more important to examine markets with reputation formation empirically. We believe that the behavior described above provides a plausible account of the forces that could be operative in the RC and, therefore, it makes sense to search for empirical patterns that match the following conjectures:

- The lenders in the RC will condition incumbents' credit renewal on their repayment behavior.

- The borrowers in the RC will repay debt in case of project success with higher probability than in the OC.

- The borrowers in the $\mathrm{RC}$ will choose the efficient project $\mathrm{A}$.

- The disciplining of the selfish borrowers will lead to higher average debt repayments in the $\mathrm{RC}$ than the $\mathrm{OC}$ and, therefore, trading activity will be higher in the $\mathrm{RC}$ than in the OC.

- The disciplining of the borrowers by the lenders' contingent renewal policy will lead to the formation of long-term trading relations between pairs of traders in the RC.

In the TPC the incentive problem associated with debt repayments is solved through the introduction of legal enforcement of repayments. However, since the borrowers' project choice is not observable for lenders the borrowers still have a discretionary leeway. We continue to assume that trustworthy borrowers honor the credit contract and choose project $\mathrm{A}$ if the contract entails a fair sharing of the project returns. Yet, recall from Section III.A that in the TPC selfish borrowers have an incentive to choose the inefficient project B for all contract conditions that lenders are willing to offer. However, choosing the inefficient project B also decreases the chances of repayment because project B is less likely to be successful. If lenders make future credit offers contingent on current debt repayments, they may again generate reputational incentives motivating selfish borrowers to choose the efficient project A. As in the $\mathrm{RC}$ contingent contract renewals may thus also alleviate the moral hazard problem in the TPC (see Proposition A3 in the Appendix). 
However, perfect pooling, i.e., a situation in which the selfish borrowers perfectly mimic the project choices of the trustworthy borrowers, can never be part of an equilibrium. The same reasons that prevent a perfect pooling equilibrium with regard to repayment choices in the RC also prevent a perfect pooling equilibrium in the TPC. If both types of borrowers behaved in exactly the same way, observed repayments would not contain any information on project choices and accordingly lenders would have no reason to condition their offers on the past repayments of their incumbent borrowers. But in the absence of a conditional offering strategy selfish borrowers would lack the incentive to choose the efficient project. Thus, in a reputational equilibrium selfish borrowers choose project $\mathrm{A}$ with a positive probability but not with certainty. This implies that repaying borrowers are more likely to be trustworthy than defaulting ones. As a consequence the lenders who are interested in interacting with trustworthy borrowers condition their offers on repayment behavior and thereby provide the necessary incentives for selfish borrowers to choose the efficient project (for details see Proposition A3 in the Appendix).

Because the contingent renewal equilibrium described above is again only one among many equilibria in the TPC the same caveat as in the RC applies, i.e., repeated game theory does not provide a perfectly tight prediction. However, this does not mean that the theory is of no help because it is still possible to use plausible equilibria as a guide for the empirical analysis. As the conditioning of credit offers on repayment behavior is a quite plausible feature of an equilibrium we put forward the following empirical conjectures:

- The lenders in the TPC will condition incumbents' credit renewal on their repayment behavior.

- Despite short-term incentives to choose project B many borrowers will choose the efficient project $\mathrm{A}$ in the TPC.

- The disciplining of the borrowers and lenders contingent renewal policy will lead to the formation of long-term trading relations between pairs of traders in the TPC.

Before we present our results it is worthwhile to point out one potentially important difference between the RC and the TPC. As we have mentioned above (and show in more detail in Proposition A2 in the Appendix), if a selfish borrower has an incentive to repay in the RC he is also strictly better of if he chooses the efficient project. In contrast, in the equilibrium described above for the TPC, the borrower does not face a strict incentive to choose project A. In fact, because the borrower's equilibrium strategy is a mixed strategy he must be indifferent between choosing project $\mathrm{A}$ and $\mathrm{B}$. Therefore, if the traders in the RC are capable of enforcing a high repayment level, we would predict that we observe a higher frequency of efficient project choices in the RC than in the TPC. 
Furthermore, we would like to emphasize that we do not think that the participants in our experiment will play the described equilibria in a narrow sense. However, we expect the forces which support these equilibria - the reputational incentives induced by conditional contract renewals in endogenously built relationships - to importantly shape the nature of credit market trading in the different conditions of our experiment.

\section{Results}

In this section we present our results. In subsection A we analyze the impact of relational reputation formation on credit market performance in the absence of legal enforcement of debt repayments. To this end we compare the credit market outcomes in the OC and the RC. In subsection B we investigate the consequences of the introduction of legal enforcement of debt repayment. This analysis is based on a comparison of the outcomes in the RC and the TPC.

\section{A. Reputation and Credit Market Formation}

In this section we show that in the $\mathrm{OC}$, where borrowers cannot acquire a reputation, credit market trading breaks down. In the $\mathrm{RC}$, in contrast, the possibility for reputation formation creates powerful incentives for debt repayment which enables the trading parties to solve the double moral hazard problem in the credit market to a high degree and reaching much higher levels of market efficiency than in the OC.

Result 1 (market breakdown in the one-shot condition): (a) In the absence of reputation formation and third party enforcement of debt repayment no stable credit market can be established and trading sharply diminishes over time. Despite the existence of a nonnegligible share of borrowers who repay credits, lending is not profitable. (b) However, in almost all trades that occur the borrowers choose the efficient project $A$.

Support for Result 1 comes from Figure I and Figure II. Figure I shows that the initial proportion of realized contracts is very high in the OC - roughly $90 \%$ of all feasible trades take place. However, there is a sharp decline in market trading already in period 4. After period 4 we observe a further gradual decline in the extent to which the available trades are exhausted until the frequency of market trading becomes very low. In the final period, only $17 \%$ of the feasible contracts are concluded. Thus, there can be little doubt that the credit market essentially breaks down in this condition.

\section{Insert Figure I about here}


Figure II provides the main reason why lenders willingness to offer credit becomes so low in the OC. Panel A of Figure II displays the borrowers' average repayments in concluded contracts. In order to evaluate this figure it is important to recall that the lenders' outside option is 32 (depicted by the grey line). The figure clearly indicates that, on average, the lenders always earned less than their outside option so that market trading was not worthwhile for them.

However, the average repayment hides some important heterogeneity among the borrowers which is displayed in the right panel of Figure II. This figure shows the percentage of contracts that were profitable from an ex ante perspective. ${ }^{13}$ Overall, roughly 30 percent of the contracts were ex ante profitable, making it worthwhile to trade in these cases. Thus, as hypothesized, there is a positive share of trustworthy borrowers who repay credits even in the OC. As a consequence, lenders did not experience a loss in every trade but could make profits in a considerable number of cases. This is likely to be the main reason why it took some time for the lenders to realize that their average profit was below their outside option. The lack of (average) profitability is also indicated by a regression of lenders' total payoffs on the number of concluded contracts in the OC; for every additional trade a lender earned on average 6 money units less (coefficient $=-6.04, \mathrm{p}=0.079$, robust standard errors clustered on sessions). ${ }^{14}$

\section{Insert Figure II about here}

The project choice data reveal that the borrowers choose project $\mathrm{A}$ in $94 \%$ of the cases. This is interesting because it is consistent with our assumption about the coexistence of selfish and trustworthy types (see Section III.B). If a borrower is selfish and plans not to repay his or her credit, then the borrower is the residual claimant of all returns. This implies that selfish borrowers should choose project A, because this maximizes their expected returns. If a borrower is trustworthy, he or she may voluntarily want to stick to the credit terms set by the lender. As most lenders (85\%) choose project A as the desired project in their contract offer, this implies that also trustworthy borrowers should mostly choose project A.

Results 1 sets the stage for studying the impact of reputation formation opportunities on credit market functioning. It shows that the existence of selfish borrowers who do not

\footnotetext{
${ }^{13}$ There are two cases in which the contract is profitable to the lender from an ex ante perspective (i.e., extending credit creates an expected profit of at least 32). The first case is that the borrower chooses project A and repays at least 40 in case of success (Expected profit $=0.8 \times 40=32$ ). The second case is that the borrower chooses project $\mathrm{B}$ and repays at least 107 (Expected profit $=0.3 \times 107 \approx 32$ ). The analysis is based on data from contracts with successful projects only. The reason is that in case of project failures we do not observe how much the borrower would have repaid if the project had been successful. However, since project success is randomly determined, this procedure does not bias our results.

14 Since observations within a session cannot be regarded as independent, the standard errors of all our regressions are clustered at the session level. For the non-parametric statistical tests (like the Mann Whitney test) we take session averages as the unit of observation.
} 
repay their debt undermines the credit market but it also indicates the potential of reputation formation to stabilize credit market trading even in finitely repeated interactions because there is a significant share of trustworthy borrowers who repay their debt in case of project success. Our next result shows that reputation opportunities have indeed a powerful effect.

Result 2 (reputation generates stable market trading): The introduction of reputation formation opportunities allows for the formation of a stable credit market such that, except for the final period, roughly 80-90\% of the feasible trades take place.

Support for Result 2 comes from Figure I and the associated statistical tests. Figure I indicates that in each of the first 19 periods of the RC at least 74 percent of the available trades take place and if we take the average over all 20 periods, we observe that 81 percent of the available contracts are concluded. This result contrasts sharply with the OC. The contrast with the OC is most visible in periods 15-19 where the gap in the share of realized contracts is roughly 50 percentage points. Thus, Figure I illustrates that the introduction of the opportunity to form long-term relationships substantially improves the stability of credit market trading. We find that the number of realized contracts is slightly decreasing over time and abruptly drops from 72 to 42 percent in the last period.

The large gap in trading activity between the $\mathrm{RC}$ and the $\mathrm{OC}$ is also confirmed by more formal statistical tests. The non-parametric Mann Whitney test with the number of contracts per session as the unit of observation indicates highly significant treatment differences $(\mathrm{p}=0.004)$.

The much higher trading activity in the $\mathrm{RC}$ indicates that reputation formation makes the extension of credit more attractive. Thus, the natural next question is: how exactly do trading parties succeed in mitigating the moral hazard problems in the RC?

Result 3 (endogenous enforcement of credit contracts in the $\mathbf{R C}$ ): If reputation formation is possible lenders condition contract renewal on the borrower's past repayment behavior. As a consequence, borrowers have a strong incentive to repay their debt after the successful realization of a project. In addition, in the vast majority of trades the borrowers choose the efficient project $A$. As a consequence, the average repayment in the $R C$ is significantly higher than in the $O C$.

We provide support for Result 3 with Table II and Figure III. Regressions 1 and 2 in Table II show the results of probit regressions in which we regress the binary variable "contract renewal in the next period" on the current repayment, the average repayment in previous 
interactions with the same lender and the number of previous interactions with the same lender. The ME-columns associated with these regressions indicate the corresponding marginal effects. In the third and fourth regression we do not use repayment levels as regressors; instead, we regress on a dummy for positive repayments in the current period and the percentage of positive repayments in previous interactions with the same lender. Table II shows that all coefficients in all regressions are positive and significant. The marginal effect for the repayment levels in columns $\mathrm{ME}[1]$ and $\mathrm{ME}[2]$ indicate that a repayment increase by 10 units in the current period increases the probability of contract renewal in the next period by 11 percent; an increase in the average repayment in all previous interactions with the current lender by 10 units increases the probability of contract renewal by 4 percent. However, an even more impressive marginal effect is indicated by columns ME[3] and $\mathrm{ME}$ [4]. A borrower who makes a positive repayment increases the chances of contract renewal by $48 \%$. On average lenders renew a contract with a borrower in $66 \%$ of the cases if he makes a positive repayment, but only in $18 \%$ of the cases if he does not repay. ${ }^{15}$ One reason for this big effect is that if the borrowers decided to repay they usually repaid a substantial amount, making the trade profitable for the lender. If we only look at positive repayments 90 percent of all observations lie in the interval $[40,60]$. This makes perfect sense in light of our argument that borrowers who repay their debt are either reciprocally motivated and prepared to comply with the conditions proposed by the lender or they pretend to have such preferences. ${ }^{16}$ The borrowers almost never make repayments between 0 and 40, as this would reveal that they have successfully realized a project but are not willing to comply with the terms requested by the lender. Because of this discontinuity in the amount of repayment there is a sharp increase in the probability of contract renewal if there is a positive repayment.

\section{Insert Table II about here}

The conditioning of contract renewal on past repayment behavior is in line with our predictions in Section III.B. This policy by the lenders generates incentives for the borrowers for repaying substantial amounts. This can be illustrated by examining how the borrowers' total payoff is related to his average repayment in all concluded contracts. If we regress individual borrowers' total payoffs on their average repayments we find that an increase in the average repayment causes a significant increase in the borrowers' payoff (coefficient $=4.61, \mathrm{p}$ $=0.064$, robust standard errors).

\footnotetext{
${ }^{15}$ Note that it is not unreasonable to renew a borrower's contract even if he fails to repay a positive amount in the current period because even the efficient project A can fail so that lack of repayment does not necessarily imply a lack of willingness to repay.

${ }^{16}$ A closer look at the desired repayments in all accepted contracts reveals, that a repayment in the interval [40, 60] can in the majority of the cases be interpreted as a compliance with the contract terms. In 65 percent of the cases the lender's desired repayments are in the interval [40,60]. In the remaining 35 percent the desired repayments are higher. However, desired repayments above 70 are very rare.
} 
The lenders' contract renewal policy may affect the borrowers' behavior in two dimensions: the project choice and the repayment after project success. Since the former choice determines the probability with which the borrower can make a positive repayment, it is the combination of the two that determines the profitability of credit contracts to lenders. In Section III.B we predicted that reputational incentives, that are strong enough to motivate the borrowers to make positive repayments after project success, also induce the borrower to choose the efficient project $\mathrm{A}$. The reason is that the short-term gains that a borrower who plans to make a positive repayment can deduce from choosing the risky project, are dominated by the implied loss in the expected continuation payoffs. Interestingly, we find that this prediction is borne out by the data. The contract renewal policy of the lenders not only motivates the borrowers to make positive repayments, but it does also not significantly lower the frequency of project A choices relative to the OC. While project A is observed in $94 \%$ of the cases in the OC, project A is still chosen in $91 \%$ of the cases in the RC. This finding is also crucial for the efficiency effects of the reputational incentives in the RC. Together, the increase in the number of trades and the high frequency of efficient project choices imply that the realized fraction of the available gains from trade increases from $46 \%$ in the OC to $66 \%$ in the RC. A one-sided Wilcoxon-Mann-Whitney test with the actual gains from trade per session as the unit of observation reveals that this difference is statistically significant $(\mathrm{p}=$ $0.047) .{ }^{17}$

The impact of the conditional contract renewals on the borrowers' repayment behavior in the RC is depicted in Panel A of Figure III. In this figure, we display borrowers' repayments after a project success in the $\mathrm{OC}$ and the RC. The figure shows that repayments are considerably higher in the RC than in the OC. A one-sided Wilcoxon-Mann-Whitney test with session averages as observations shows that the difference in repayments after project success is statistically significant $(\mathrm{p}=0.004)$.

Panel A of Figure III also shows that the repayments after project success decline strongly in the final two periods of the RC. This evidence suggests that selfish borrowers are no longer disciplined by reputation incentives towards the end of the experiment. Furthermore, the borrowers' repayment behavior in the last two periods also explains the endgame effect in the number of realized contracts (see Figure I). It is evident that there is a good reason for lenders to back away from the credit market near the end of the experiment,

\footnotetext{
${ }^{17}$ Note that the actual gains from trade contain a substantial element of randomness because of the randomness involved in project success. Therefore, the p-values are somewhat lower for the actual gains from trade. We also ran a number of regressions with the realized number of trades and the actual gains from trade as the dependent variable, a treatment dummy for RC and various dummy variables for different time intervals and interactions between time intervals and the treatment dummy. All regressions show a clear picture: the RC treatment significantly increases the number of trades and the gains from trade relative to the OC.
} 
because many of the selfish borrowers who repaid out of reputational concerns now simply maximize their short-term profits and keep the whole project returns to themselves.

\section{Insert Figure III about here}

Even more direct evidence for the presence of a strong disciplining effect for the selfish borrowers comes from Panel B of Figure III. In this figure we show for every borrower the frequency of positive repayments during periods 1-18 together with the frequency of positive repayments in period 19-20. The larger the size of a bubble the more individuals are represented by the bubble. The figure indicates that there are a considerable number of individuals who repay their debt in more than $70 \%$ of the cases in periods $1-18$ but pay back nothing in periods 19-20. This pattern neatly documents the disciplining of the selfish subjects. However, the figure also shows that there is a non-negligible number of inherently trustworthy individuals who repay positive amounts even in periods 19-20.

As our next result shows, the alleviation of the moral hazard problems through contract renewal for reputable borrowers also leads to a fundamental change in market interactions because borrowers and lenders interact repeatedly with each other.

Result 4 (long-term relations dominate market trading): In the $R C$ the majority of trades is concluded by pairs who trade at least five times with each other and trading partners who interact repeatedly with each other earn significantly more than those who change their partner frequently.

Support for Result 4 comes from Figure IV which displays the cumulative frequency of trades concluded by pairs in repeated interactions with a varying number of periods. As a bechmark we also show the data for the OC because there the traders could not choose their trading partners and did not know if they happened to be matched with the same trader repeatedly. Thus, the difference between the OC and the RC shows the extent to which the traders in the $\mathrm{RC}$ deliberately engaged in repeated interactions (as compared with only coincidental multiperiod trading in the $\mathrm{OC}$ ). The large difference between the conditions indicates that the participants in the RC successfully formed trading relations. In fact, in the RC the majority of trades are concluded by pairs who interact at least five times with each other.

\section{Insert Figure IV about here}

If it is true that the lenders' conditional renewal policy disciplines the borrowers and leads to higher repayments then we should also observe that borrowers who often interact with the same lender choose the efficient project A more frequently and repay on average higher amounts. To examine this question we constructed Figure V which displays the 
percentage of efficient projects chosen in realized contracts and the average repayments after a projects success conditional on the number of interactions in the same pair. The figure indicates that more frequent interactions are indeed associated with a higher frequency of efficient project choices and higher average repayments. Thus, all the facts support the view that reputation formation opportunities and the associated constraints on the borrowers' behavior greatly alleviate the double moral hazard problem inherent in our credit market.

\section{Insert Figure V about here}

In order to examine how the involvement in repeated interactions affects lenders' and borrowers' profits we measure the extent to which each individual has succeeded in establishing relationships. The simplest possible measure would be the maximal number of interactions with the same trading partner. However, this is a very crude measure that ignores the possibility that some participants may establish relations with more than one partner over the duration of the experiment. Therefore we use a slightly more complex indicator which we call the intensity of repeated interactions (IRI). By using the IRI, we take an individual's full range of repeated interactions into account. The IRI is calculated as follows: IRI = $\sum_{i=1}^{n}\left[T_{i}^{2} / 20^{2}\right]$, where $T_{i}$ is the number of trades with trading partner $i$ and $n$ is the number of potential trading partners ( $n=10$ for lenders and $n=7$ for borrowers). The IRI is maximal if a market participant interacts with the same trading partner in all 20 periods $($ IRI $=1)$ and minimal if a market participant always chooses his outside-option (IRI $=0$ ). In between these two extreme cases the IRI is the higher, the more a market participant succeeds in repeatedly interacting with trading partners.

The IRI enables us to answer the question whether traders with a higher IRI earn on average higher profits. If we regress individual traders' average profits per period on their IRI's we find that both lenders' and borrowers' IRI is significantly and positively correlated with their profits (lenders: coefficient $=13.25, \mathrm{p}=0.004$, robust standard errors clustered on session level; borrowers: coefficient $=20.15, \mathrm{p}=0.008$, robust standard errors clustered on session level). Thus, the more a trader succeeded in establishing long term relations, the higher their profits. This result is particularly remarkable for the borrowers' because the establishment of a trading relationship was only possible if the borrower's repayments were sufficiently high. Thus, the positive impact of the IRI on the borrowers' profits is a further indication that it was profitable for the borrowers in the RC to repay their debt.

\section{B. Reputation and Third Party Enforcement of Repayments}

In the previous section we have seen that reputation formation opportunities go a long way towards solving the double moral hazard problem in our credit market. In this section we 
examine how credit markets are affected if one of the two moral hazard problems - the repayment problem - is solved by legal enforcement. A first intuition might lead one to believe that if only the project choice problem remains, it might be easier to solve this problem with reputational incentives. However, as we have seen in Section III.B, the introduction of third party enforcement might exacerbate the project choice problem. Our next result shows that this is indeed the case.

\section{Result 5 (market trading and project choice under third party enforcement): The} introduction of third party enforcement of debt repayment causes a further significant increase in the number of trades but it also leads to a significant reduction in the share of efficient projects so that the efficiency gains from third party enforcement are relatively small.

We provide support for the first part of Result 5 by means of Figure II. This figure indicates that in almost all periods the share of realized contracts is higher in the third party condition (TPC) than in the RC. This difference is also statistically significant according to a Mann Whitney test with session averages as the unit of observation $(\mathrm{p}=0.008)^{18}$. However, the realized gains from trade are only somewhat higher in the TPC compared to the RC $-72 \%$ in the TPC and $66 \%$ in the RC. Moreover, this difference is not statistically significant (Mann Whitney test with session averages as unit of observations, $p=0.247$ ).

If efficiency does not increase although the number of trades is significantly higher in the TPC, project choices must differ across conditions. Our theoretical analysis in Section III.B (see page 15) suggests that borrowers may face weaker incentives to choose project A in the TPC than in the RC. And indeed, in more than half of the trades (54\%) the borrowers choose the inefficient project B in the TPC while in the RC the borrowers choose project B in only $9 \%$ of the cases. This difference is highly significant (Mann Whitney test with session averages as unit of observations, $\mathrm{p}=0.004)$.

One important reasons why the borrowers choose the inefficient project much more often in the TPC than in the RC is that the borrowers in the TPC face much stronger shortterm incentives to choose project B. Due to the legal enforceability of debt repayments, the choice of project B always maximized the borrowers' period profit in the TPC. In the RC, in contrast, this was not the case. Despite the fact that reputational forces greatly alleviated the repayment problem in the $\mathrm{RC}$, borrowers did still not repay anything in $17.5 \%$ percent of the successful projects. In these $17.5 \%$ of the cases, the borrower had the incentive to choose the

\footnotetext{
${ }^{18}$ We also ran several regressions with the realized number of trades as the dependent variable, a treatment dummy for RC and various dummy variables for different time intervals and interactions between time intervals and the treatment dummy. All these regressions reveal the same picture: the TPC significantly increases the number of trades.
} 
efficient project A because he earned the whole project return. Furthermore, lenders in the TPC requested much higher repayments in case of a project success than in the RC which increases the short term incentive to choose project B. Thus, even in the cases where they planned to make the repayment requested by the lender, borrowers in the RC had less strong incentives to choose project B than the borrowers in the TPC. In Table III we show how much borrowers can gain if they choose project B although the lender asks for project A in the RC and the TPC. The table illustrates that the difference in the borrowers' expected profits between project $\mathrm{A}$ and $\mathrm{B}$ differs substantially across conditions. The relative short term attractiveness of project $\mathrm{B}$ - as measured by the expected profit of project $\mathrm{B}$ relative to project $\mathrm{A}-$ is considerably higher in the TPC than in the RC.

\section{Insert Table III about here}

Table III is based on data from contracts in which the lender's desired project is project A. The table displays expected period profits of borrowers for each possible project choice. ${ }^{19}$ In trades carried out by a lender and a borrower who interact infrequently with each other (1-3 times over the experiment) choosing project A yields a slightly higher expected profit for the borrower in the $\mathrm{RC}$ while project $\mathrm{B}$ yields a much higher expected profit in the TPC. If a pair of traders interacted repeatedly with each other (between 4 and 10 times or between 11 and 20 times, respectively) project B yields higher expected payoffs for borrowers both in the RC and the TPC. However, the difference in expected profits between the two projects is much larger in the TPC, indicating that borrowers have a stronger short-term incentive to choose project B in the TPC than in the RC. Thus, for given reputational incentives (arising from contingent contract renewals) the borrowers have stronger incentives to choose the inefficient project B in the TPC.

The fact that the introduction of third party enforcement exacerbates the project choice problem implies that the provision of reputational incentives may still be of high value in the TPC. Since a borrower can increase the probability of repayment by choosing the efficient project, the lenders can provide reputational incentives to choose project A by making contract renewals dependent on past repayment behavior. Our next result addresses, therefore,

\footnotetext{
${ }^{19}$ In the TPC the fact that desired repayments are enforceable makes it easy to calculate borrowers' expected profits. The database consists of all concluded contracts in which the lender desired project A. Expected profits are calculated as: Expected profit $=$ Probability of success x (Project return - Desired repayment). In the RC, in contrast, the desired repayment is not binding and the borrower can repay as much as he wants. In this case the data base consists of all accepted contracts in which the lender desired project A and the borrower successfully completed a project (either A or B). Expected profits are calculated as: Expected profit = Probability of success $\mathrm{X}$ (Project return - Observed repayment). We can only consider contracts with successful projects because intended repayments are not observable in case of project failure. As project success is random, this does not bias our results. Our calculations for the RC implicitly assume that borrowers would have made the same repayment, if they had chosen the other project. The data support this assumption: the borrower's actual project choice does not significantly affect the repayment level in contracts in which the lender desired project A. This makes sense, if we take into account that borrowers have always incentives to pretend that they have chosen project A.
} 
the question whether borrowers face such reputational incentives in the TPC and how strong they are in comparison to the $\mathrm{RC}$

Result 6 (endogenous enforcement of efficient project choices): Under third party enforcement of repayments the lenders condition contract renewal on the borrower's past repayment behavior but the impact of past repayments on contract renewal is weaker than in the RC. Nevertheless, contingent contract renewal also leads to repeated interactions between borrowers and lenders in the TPC.

Result 6 means that the borrowers in the TPC do not only face stronger short-term incentives to choose the inefficient project but they also face weaker reputational incentives to choose the efficient project A. Taken together these facts provide a plausible explanation for why we observe much fewer efficient project choices in the TPC.

Support for Result 6 comes from Table IV which shows probit regressions with data from the TPC and the RC in which the binary variable "contract renewal in the next period" is the dependent variable. Regressions 1 and 2 compare the impact of the current repayment, the average repayment in previous interactions with the same lender and the number of previous interactions with the same lender on the probability of a contract renewal in the next period. The corresponding ME-columns report the marginal effects. ${ }^{20}$ The significantly negative interaction effect of the TP dummy and the current repayment level (see columns ME[1] and ME[2]) indicates that the current repayment level has a weaker positive impact on the probability of contract renewal in the next period. Regressions 3 and 4 confirm this finding with a different set of right-hand side variables. Instead of current and past repayment levels we use a dummy for positive current repayments and the percentage of positive repayments in previous interactions as regressors. In both regressions the interaction between the dummy for positive repayments and the TPC dummy is negative, significant and sizeable. This result means a positive repayment in the TPC did not increase a borrower's chances of a contract renewal in the same way as in the RC: a positive repayment in period $t$ increases the chances of a contract renewal in the TPC by about 10 to 13 percentage points less than in the RC. This implies that that there are less strong incentives to choose the low risk project A in the TPC than in the RC.

\section{Insert Table IV about here}

\footnotetext{
${ }^{20}$ Since the interaction effect does not correspond to the marginal effect of the interaction term in non-linear estimations, we used the procedure recommended by Ai and Norton (2003) to estimate the correct interaction effects.
} 
Yet, despite this decrease in contingency of contract renewals the borrowers in the TPC still face reputational incentives. A positive repayment increases the probability of a contract renewal by about 30 percentage points (see columns ME[3] and ME[4]). That these incentives have important consequences for the prevalence of repeated interactions in the TPC is illustrated by the fact that the cumulative frequency of trades in the TPC - which is shown in Figure VI - resembles the one in the RC: a substantial share of the trades is executed by trader pairs that interact many times with each other.

\section{Insert Figure VI about here}

The lower degree of contingency in contract renewals also does not mean that contingent contract renewal did not have an effect on project choices and average repayments. Figure VII shows that in relations lasting more than 10 periods project A was chosen in more than 70 percent of the cases and the average repayments were therefore, rather high. Yet, in relations that lasted less than 10 periods the efficient project is only chosen in less than $40 \%$ of the cases. As a consequence, borrowers and lenders benefited from the establishment of long-term relations: if we regress profits on the intensity of repeated interactions (IRI) in the TPC we observe that a higher IRI is associated with higher profits for both lenders and borrowers (lenders: coefficient $=14.42, \mathrm{p}=0.006$, robust standard errors clustered on session level; borrowers: coefficient $=24.51, \mathrm{p}=0.021$, robust standard errors clustered on session level).

\section{Insert Figure VII about here}

\section{Conclusions}

In this paper we experimentally investigate how reputation formation in endogenously built relationships affects credit market performance and how these relational incentives interact with improvements in the legal enforceability of debt repayments. When legal institutions are weak and repayments cannot be exogenously enforced we find that the disciplining effect of relational incentives is a decisive determinant for the existence and functioning of credit markets. In the condition where reputation formation opportunities are exogenously excluded the lack of repayment incentives leads to a breakdown of credit market activity. However, when we allow that borrowers can acquire a reputation, stable credit markets emerge in which roughly $80 \%$ of all feasible trades take place. By conditioning access to future credits on previous debt repayments, lenders create powerful incentives for borrowers to repay their debt out of reputational concerns. Borrowers respond to these incentives by choosing efficient projects and a high repayment rate. As a consequence, many mutually beneficial trades take place. 
This finding is interesting with regard to the literature on relationship banking. Theoretically, it has often been argued that the prevalence of bilateral borrower-lender relationships may be due to the disciplining effect of contingent contract renewals. However, so far existing field data has not allowed separating this effect from the alternative explanation that relationships are attractive because they provide lenders with better access to the borrower's books and therewith lead to the selection of better borrowers. Our experiment enables us to show the positive impact of the disciplining effect on credit market performance in a clean and controlled way.

When the legal credit market environment improves, we observe an interesting interaction effect between relational incentives and the exogenous enforcement of debt repayments. While the legal enforceability of debt repayment causes a significant increase in credit market trading, it has only a small positive impact on credit market efficiency. The reason is that in the presence of limited liability and wealth constraints the legal enforcement of debt repayments motivates many borrowers to choose inefficiently risky projects. Endogenous contract enforcement in relationships does only partly offset this effect. Thus, legal enforcement provides not only a powerful solution to the moral hazard problem associated with debt repayment, but it also exacerbates the moral hazard problem that is associated with the incentive to choose inefficient high risk projects.

To the best of our knowledge, the possibility that legal enforcement weakens reputational incentives and increases the frequency of inefficient project choices has not been discussed before. Our finding that legal and endogenous enforcement mechanisms may have important interactions suggests that these effects should be studied more extensively in future work. 


\section{Appendix}

In this appendix we show the existence of reputation equilibria in a two-period version of the game implemented in our experiment. It is not our objective to provide a complete formal analysis of our experimental game. We rather want to show that in the RC and the TPC there are perfect Bayesian equilibria in which the reputation mechanisms intuitively described in Section III.B are at work.

As outlined in the text, we assume that there are two types of borrowers: A share $x \in$ $(0,1)$ are trustworthy types, i.e. they are willing to honor the credit terms set by the lender as long as they perceive them as fair. The rest of the borrowers are purely selfish profitmaximizers. We assume that the trustworthy borrowers perceive a credit offer as fair if the lender asks for the efficient project and if the desired repayment $r^{d}$ ensures that the return in case of project success is shared in a fair manner, i.e. a fair contract offer must be of the form $\left(p^{d}=\mathrm{A}, r^{d} \leq r^{t}\right)$, where $r^{t}$ is the maximal repayment a trustworthy borrower considers as fair. ${ }^{21}$

For tractability reason we slightly simplify the posting and acceptance of credit offers. In the experiment the trading mechanism is a continuous auction. However, as continuous auctions have defied a fully rigorous analysis so far, we approximate the bargaining process with a posted contract mechanism. Specifically, we assume that each lender can only make one credit offer, either a public offer or a private offer in every period. Borrowers then choose in random order from the available offers. Each borrower is free to accept one of the loans available to him or not to borrow at all.

\section{A. Credit Market Trading in the OC}

We first analyze the behavior of risk-neutral lenders and borrowers in the OC, in which neither legal enforcement of debt repayments nor the possibility for reputation formation are present. Proposition A1 shows that in the OC credit market trading can only take place if there is a sufficiently large share of trustworthy borrowers.

\section{Proposition A1:}

In the OC lenders are only willing to offer credit contracts to borrowers if the fraction of trustworthy borrowers satisfies $x \geq k /\left(w^{A} r^{t}\right)$, otherwise lenders make use of the endowmentstoring technology.

\footnotetext{
${ }^{21}$ It is plausible that $r^{t}$ depends on the presence of legal enforcement of debt repayments. As the presence of third party enforceability of repayments puts lenders into a stronger position trustworthy borrowers may be prepared to regard higher repayment requests as fair when repayments are enforceable than when they are not. To keep our exposition as simple as possible, we do not explicitly include this possibility in our notation.
} 


\section{Proof:}

In the OC selfish borrowers simply maximize their period profits, i.e., they choose project A and never repay after project success. Trustworthy borrowers, in contrast, are willing to honor the contract terms if they are offered a contract of the form $\left(p^{d}=\mathrm{A}, r^{d} \leq r^{t}\right)$. If a lenders offer such a contract to a borrower of unknown type, his expected profit is $\mathrm{E}\left[\pi_{L}\right]=x w^{A} r^{d}$. Since the lender's expected profit is increasing in $r^{d}$ it is profit-maximizing to set $r^{d}=r^{t}$. As a lender can always realize a profit of $k$ by choosing the endowment-storing technology, he is only prepared to offer a credit contract to an unknown borrower if the following offer condition is satisfied $x \geq k /\left(w^{A} r^{t}\right)$.

\section{B. Credit Market Trading in the RC}

We next consider the RC. For simplicity and expositional clarity we consider only a twoperiod version of the game. In line with our empirical observations in the laboratory we assume that the fraction of trustworthy borrowers is insufficient to make credit contracts profitable in the OC, i.e., $x<k /\left(w^{A} r^{t}\right)$. Proposition A2 shows that in the RC reputation effects make it possible that there is a perfect Bayesian equilibrium in which lenders are willing to extend credit even if the parameters are such that no credit market can exists in the OC.

\section{Proposition A2:}

Consider the RC and assume that the fraction of trustworthy borrowers lies in the following range: $\left[k /\left(w^{A} r^{t}\right)\right]^{2} \leq x<k /\left(w^{A} r^{t}\right)$. There is a perfect Bayesian equilibrium with the following characteristics: In period 1 all lenders make a public credit offer of the form $\left(p^{d}=\mathrm{A}, r^{d}=r^{t}\right)$. A random selection of 7 borrowers accepts these offers and chooses project A. In case of project success trustworthy borrowers repay $r=r^{t}$ with certainty, while selfish borrowers repay $r=r^{t}$ with probability $s=x\left(w^{A} r^{t}-k\right) /[(1-x) k]$. In period 2 each lender whose incumbent borrower has repaid the loan in period 1 privately offers a credit contract of the form $\left(p^{d}=\mathrm{A}, r^{d}=r^{t}\right)$ with probability $l=r^{t} /\left(w^{A} R^{A}-b\right)$ to his incumbent borrower, while each lender whose incumbent borrower has defaulted in period 1 always chooses the endowment-storing technology. Those borrowers who get a credit offer choose project A. In case of project success trustworthy borrowers repay $r=r^{t}$ with certainty while selfish borrowers never repay.

\section{Proof:}

Proof is by construction and is established in three steps:

Step 1 (project choice and repayments of trustworthy borrowers): 
We have assumed that trustworthy borrowers who get a contract of the form $\left(p^{d}=\mathrm{A}, r^{d} \leq r^{t}\right)$ honor the contract terms suggested by the lender if possible. Thus, all trustworthy borrowers who succeed in accepting a contract $\left(p^{d}=\mathrm{A}, r^{d}=r^{t}\right)$ in period 1 and 2 choose project $\mathrm{A}$ and repay after project success.

Step 2 (project choice and repayments of selfish borrowers):

Since period 2 is the final period selfish borrowers behave exactly as in the OC: whenever they succeed in getting a contract they maximize their period profit by choosing project A and not repaying in case of project success. Thus, if a selfish borrower gets a contract in period 2 , his expected profit is $\mathrm{E}\left[\pi_{B}\right]=w^{A} R^{A}$.

In period 1 the situation is different. Let us start with the repayment decision. Assume that a selfish borrower has accepted a contract $\left(p^{d}=\mathrm{A}, r^{d}=r^{t}\right)$ and has successfully realized a project (it may be A or B). The borrower must now choose one of two repayments: Either he imitates the behavior of a trustworthy borrower and repays $\left(r=r^{t}\right)$ or he does not repay at all $(r=0) .^{22}$ In period 1 repaying may make sense if lenders condition the probability of a contract renewal in period 2 on the borrower's repayment behavior. Define $l(r)$ as the probability with which a lender renews his contract with a borrower in period 2 after observing the repayment $r$ in period 1. After repaying $r$ in period 1 a selfish borrower then faces the following continuation payoff for period 2: $V(r)=l(r) w^{A} R^{A}+(1-l(r)) b$. This implies that a selfish borrower is willing to make a repayment $r=r^{t}$ if the following repayment condition is satisfied: $r^{t} \leq V\left(r^{t}\right)-V(0)=\left(l\left(r^{t}\right)-l(0)\right)\left(w^{A} R^{A}-b\right)$.

Let us now move on to the project choice. Using the notation from above, we can write the expected stream of utility over both periods, which is implied by the choice of a project $p \in\{\mathrm{A}, \mathrm{B}\}$ in period 1 as: $w^{p}\left[s\left(R^{A}-r^{t}+V\left(r^{t}\right)\right)+(1-s)\left(R^{A}+V(0)\right)\right]+\left(1-w^{p}\right) V(0)$. Thus, a selfish borrower prefers project $\mathrm{A}$ over project $\mathrm{B}$ as long as the following project choice condition is satisfied: $s\left(w^{A}-w^{B}\right)\left[-r^{t}+V\left(r^{t}\right)-V(0)\right]+w^{A} R^{A}-w^{B} R^{B}>0$. Since $w^{A}>w^{B}$ and $w^{A} R^{A}>w^{B} R^{B}$, it is straightforward to see that the repayment condition is a sufficient (but not necessary) condition for the project choice condition.

The lenders' contract renewal probabilities given in Proposition A2 imply that the repayment condition is satisfied with equality, i.e., a selfish borrower is indifferent between repaying and not repaying after the realization of a successful project in period 1.

\footnotetext{
${ }^{22}$ A positive repayment $r<r^{t}$ is never optimal. Such a repayment is not in line with a trustworthy borrower's behavior and would therefore reveal the selfish borrower's type. However, if the borrower reveals his type anyway, then he is always better off by repaying nothing.
} 
Accordingly, any repayment probability $s \in[0,1]$ is optimal. Furthermore, the fact that the repayment condition is satisfied implies that also the project choice condition is satisfied.

\section{Step 3: Sequential Rationality and Credit Contract Offers of Lenders}

Sequential rationality requires that a lender's belief $y$ about the trustworthiness of a borrower is defined at every information structure in the game. The initial prior, that is the probability that a lender assigns to the event that an unknown borrower is trustworthy, is given by the population fraction of trustworthy borrowers: $y(\varnothing)=x$. If a lender interacts with a borrower in period 1 he updates his belief about the trustworthiness of this borrower based on the observed repayment using Bayes' Rule. Accordingly, the lender's belief after a repayment of $r=r^{t}$ is given by $y\left(r^{t}\right)=x /[x+(1-x) s]$, while the lender's belief after default $(r=0)$ is given by $y(0)=\left(1-w_{A}\right) x /\left[\left(1-w_{A}\right)+w_{A}(1-x)(1-s)\right]$.

Let us now turn to the credit offers of lenders. In period 2 lenders anticipate that borrowers face the same incentives as in the OC. Accordingly, Proposition A1 implies that a lender is only willing to make a credit offer to a specific borrower if his belief satisfies the offer condition: $y>k /\left(w^{A} r^{t}\right)$. Since we assume that $\mathrm{x}<k /\left(w^{A} r^{t}\right)$ (no credit market trading in OC) a borrower who does not repay in period 1 does not get a credit offer in period 2 . The reason is that the lender's belief cannot satisfy the offer condition: $y(0) \leq x<k /\left(w^{A} r^{t}\right)$. This implies that the contract renewal probability after default is zero: $l(0)=0$.

In order to get a credit offer after repaying in period 1 the selfish borrower's repayment probability has to be low enough such that the lender's updated belief at the beginning of period 2 has at least increased to the necessary threshold value: $y\left(r^{t}\right) \geq k /\left(w^{A} r^{t}\right)$. This yields the following condition for the selfish borrower's repayment probability: $s \leq$ $x\left(w^{A} r^{t}-k\right) /(1-x) k<1$. Given that $l(0)=0$ the repayment condition from Step 2 implies that this repayment probability can only be best response of a selfish borrower if the lender's contract renewal probability after repayment is given by $l\left(r^{t}\right)=r^{t} /\left(w^{A} R^{A}-b\right)$. However, this contract renewal probability can only be a best a response of the lender, if the lender is indifferent between offering a contract and choosing the endowment-storing technology. Accordingly, the lender's belief must be exactly at the threshold level, i.e., $y\left(r^{t}\right)=k /\left(w^{A} r^{t}\right)$. This, in turn, implies that $s=x\left(w^{A} r^{t}-k\right) /(1-x) k$. Furthermore, in period 1 lenders are only willing to offer a contract if the total probability of getting a repayment ensures that they are at least indifferent between offering a contract and their outside-option. This requires that $x+$ $(1-x) s=k /\left(w^{A} r^{t}\right)$. Given the repayment behavior of selfish borrowers in period 1 this 
condition can only be satisfied if the initial fraction of trustworthy borrowers is not too low: $x$ $\geq\left[k /\left(w^{A} r^{t}\right)\right]^{2}$.

\section{Credit Market Trading in the TPC}

We now turn to the TPC, in which repayments of borrowers after project success are legally enforced. In Section III.A we show that in this setup maximization of short-term borrower profits requires the choice of project $\mathrm{B}$. In the absence of trustworthy borrowers, lenders anticipate that project $\mathrm{A}$ is never chosen and they therefore offer a contract of the form $\left(p^{d}=\right.$ $\left.\mathrm{B}, r^{d}=r^{s}\right)$, where $r^{s}=\left(w_{B} R_{B}-b\right) / w_{B}$ is a high repayment which makes the borrower only slightly better off than his outside option. ${ }^{23}$ If there is a large fraction of trustworthy borrowers, lenders may - even in the absence of reputational incentives - prefer to offer a contract of the form $\left(p^{d}=\mathrm{A}, r^{d}=r^{t}\right)$. However, we assume that the fraction of trustworthy borrowers is not large enough to render such a contract profitable in a one-shot interaction, i.e., $x \leq w^{B}\left(r^{s}-r^{t}\right) /\left(w^{A}-w^{B}\right) r^{t}{ }^{24}$ Proposition A3 shows that in the TPC reputation effects make it possible that there is a perfect Bayesian equilibrium in which lenders offer contracts of the form $\left(p^{d}=\mathrm{A}, r^{d}=r^{t}\right)$ despite the fact that the parameters are such that these contracts are not profitable in one-shot interactions.

\section{Proposition A3:}

Consider the TPC and assume that the fraction of trustworthy borrowers lies in the following range: $\left(w^{B}\right)^{2} r^{s}\left(r^{s}-r^{t}\right) / w^{A}\left(w^{A}-w^{B}\right)\left(r^{t}\right)^{2} \leq x<w^{B}\left(r^{s}-r^{t}\right) /\left(w^{A}-w^{B}\right) r^{t}$. There is a perfect Bayesian equilibrium with the following characteristics: In period 1 all lenders make a public credit offer of the form $\left(p^{d}=\mathrm{A}, r^{d}=r^{t}\right)$. A random selection of 7 borrowers accepts these offers. Trustworthy borrowers who have accepted a contract choose project A with certainty, while selfish borrowers who have accepted a contract choose project A with probability $z=$ $\left[w^{A}\left(w^{A}-w^{B}\right) x r^{t}-w^{B}\left(x w^{A}-(1-x) w^{B}\right)\left(r^{s}-r^{t}\right)\right] /\left[w^{B}\left(w^{A}-w^{B}\right)(1-x)\left(r^{s}-r^{t}\right)\right]$. In period 2 each lender, whose borrower has repaid in period 1, privately offers a credit contract of the form $\left(p^{d}=\mathrm{A}, r^{d}=r^{t}\right)$ with probability $m=\left[w^{B}\left(R^{B}-r^{t}\right)-w^{A}\left(R^{A}-r^{t}\right)\right] /\left[\left(w^{A}-w^{B}\right)\left(w^{B}\left(R^{B}-r^{t}\right)-b\right)\right]$ to his incumbent borrower, while each lender whose incumbent borrower has defaulted in period 1 always makes a public credit offer of the form $\left(p^{d}=\mathrm{B}, r^{d}=r^{s}\right)$ to his incumbent borrower. Trustworthy borrower choose project A if they receive a contract offer of the form $\left(p^{d}=\mathrm{A}, r^{d}=r^{t}\right)$ and project $\mathrm{B}$ if they receive a contract offer $\left(p^{d}=\mathrm{B}, r^{d}=r^{s}\right)$. Selfish borrowers choose project B irrespective of the form of their contract.

\footnotetext{
${ }^{23}$ Under the parameter conditions in the experiment this equivalent to a repayment of 166 (see Section III.A).

${ }^{24}$ In the absence of reputational incentives the expected profit if the lender offers the contract $\left(p^{d}=\mathrm{B}, r^{d}=r^{s}\right)$ is $w^{B} r^{s}$, while the expected profit if he offers the contract $\left(p^{d}=\mathrm{A}, r^{d}=r^{t}\right)$ is $\left(x w^{A}+(1-x) w^{B}\right) r^{t}$.
} 


\section{Proof:}

Proof is by construction and is established in three steps:

Step 1 (project choice of trustworthy borrowers):

We have assumed that trustworthy borrowers who get a contract of the form $\left(p^{d}=\mathrm{A}, r^{d} \leq r^{t}\right)$ honor the contract terms suggested by the lender if possible. Thus, all trustworthy borrowers who succeed in accepting a contract $\left(p^{d}=\mathrm{A}, r^{d}=r^{t}\right)$ in period 1 and 2 choose project $\mathrm{A}$. However, trustworthy borrowers who are offered a contract $\left(p^{d}=\mathrm{B}, r^{d}=r^{s}\right)$ choose project $\mathrm{B}$.

Step 2 (project choice and repayments of selfish borrowers):

Since period 2 is the final period selfish borrowers behave exactly as in a one-shot interaction: whenever they succeed in getting a contract they maximize their period profit by choosing project B. Thus, if a selfish borrower gets a contract $\left(p^{d}=\mathrm{A}, r^{d}=r^{t}\right)$ in period 2, his expected profit is $\mathrm{E}\left[\pi_{B}\right]=w^{B}\left(R^{B}-r^{t}\right)$. If he gets a contract $\left(p^{d}=\mathrm{B}, r^{d}=r^{s}\right)$ his expected profit is identical to his outside option $\mathrm{E}\left[\pi_{B}\right]=w^{B}\left(R^{B}-r^{s}\right)=b$.

In period 1 the situation is different. Assume that a selfish borrower has accepted a contract $\left(p^{d}=\mathrm{A}, r^{d}=r^{t}\right)$. Since project A has a higher success probability, choosing project A may make sense if the lender conditions the probability with which he offers another contract of the form $\left(p^{d}=\mathrm{A}, r^{d}=r^{t}\right)$ to his borrower in period 2 on the borrower's repayment behavior. Define $m(r)$ as the probability with which a lender renews his contract with his borrower in period 2 after observing the repayment $r$ in period 1. After a repayment $r$ in period 1 a selfish borrower's continuation payoff for period 2 is: $V(r)=m(r) w^{B}\left(R^{B}-r^{t}\right)+(1-m(r)) b$. This implies that a selfish borrower is willing to choose project $\mathrm{A}$ if the following project choice condition is satisfied: $w^{B}\left(R^{B}-r^{t}\right)-w^{A}\left(R^{A}-r^{t}\right) \leq\left(w^{A}-w^{B}\right)\left(V\left(r^{t}\right)-V(0)\right)$, where the difference in continuation payoffs can be rewritten as $V\left(r^{t}\right)-V(0)=\left(m\left(r^{t}\right)-m(0)\right)\left(w^{B}\left(R^{B}-r^{t}\right)-b\right)$.

The lenders' contract renewal probabilities given in Proposition A3 imply that the project choice condition is satisfied with equality, i.e., a selfish borrower is indifferent between project A and project B. Accordingly, any probability $z \in[0,1]$ of choosing project A is optimal.

\section{Step 3: Sequential Rationality and Credit Contract Offers of Lenders}

Sequential rationality requires that a lender's belief $y$ about the trustworthiness of a borrower is defined at every information structure in the game. The initial prior, that is the probability that a lender assigns to the event that an unknown borrower is trustworthy, is given by the population fraction of trustworthy borrowers: $y(\varnothing)=x$. If a lender interacts with a borrower in 
period 1 he updates his belief about the trustworthiness of this borrower based on the observed repayment using Bayes' Rule. Accordingly, the lender's belief after a repayment of $r=r^{t}$ is given by $y\left(r^{t}\right)=w^{A} x /\left[w^{A}(x+(1-x) z)+w^{B}(1-x)(1-z)\right]$, while the lender's belief after default $(r=0)$ is $y(0)=\left(1-w^{A}\right) x /\left[\left(1-w^{A}\right)(x+(1-x) z)+\left(1-w^{B}\right)(1-x)(1-z)\right]$.

Let us now turn to the credit offers of lenders. In period 2 lenders anticipate that borrowers face the same incentives as in a one-shot interaction. Accordingly, a lender is only willing to make a credit offer to a specific borrower if his belief about this borrower satisfies the condition: $y>w^{B}\left(r^{s}-r^{t}\right) /\left(w^{A}-w^{B}\right) r^{t}$ (see above). Since we assume that the population fraction of trustworthy borrowers satisfies $\mathrm{x}<w^{B}\left(r^{s}-r^{t}\right) /\left(w^{A}-w^{B}\right) r^{t}$, a borrower who does not repay in period 1 does not get a renewed contract from his lender in period 2. The reason is that the lender's belief cannot satisfy the required condition: $y(0) \leq x<w^{B}\left(r^{s}-r^{t}\right) /\left(w^{A}-\right.$ $\left.w^{B}\right) r^{t}$. This implies that the contract renewal probability after default is zero: $m(0)=0$.

In order to get a credit offer after repaying in period 1 the selfish borrower's probability of choosing project A has to be low enough such that the lender's updated belief at the beginning of period 2 has at least increased to the necessary threshold value: $y\left(r^{t}\right) \geq w^{B}\left(r^{s}\right.$ $\left.-r^{t}\right) /\left(w^{A}-w^{B}\right) r^{t}$. This yields the following condition for the selfish borrower's probability of choosing the project B: $z \leq\left[w^{A}\left(w^{A}-w^{B}\right) x r^{t}-w^{B}\left(x w^{A}+(1-x) w^{B}\right)\left(r^{s}-r^{t}\right)\right] /\left[w^{B}\left(w^{A}-w^{B}\right)(1-\right.$ $\left.x)\left(r^{s}-r^{t}\right)\right]<1$. Given that $m(0)=0$ the project choice condition from Step 2 implies that this repayment probability can only be best response of a selfish borrower if the lender's contract renewal probability after repayment is given by $m\left(r^{t}\right)=\left[w^{B}\left(R^{B}-r^{t}\right)-w^{A}\left(R^{A}-r^{t}\right)\right] /\left[\left(w^{A}-\right.\right.$ $\left.\left.w^{B}\right)\left(w^{B}\left(R^{B}-r^{t}\right)-b\right)\right]$. However, this contract renewal probability can only be a best response of the lender, if the lender is indifferent between offering the contract $\left(p^{d}=\mathrm{A}, r^{d}=r^{t}\right)$ to his incumbent borrower and making a public credit offer of the form $\left(p^{d}=\mathrm{B}, r^{d}=r^{s}\right)$. Accordingly, the lender's belief must be exactly at the threshold level, i.e., $y\left(r^{t}\right)=w^{B}\left(r^{s}-r^{t}\right) /$ $\left(w^{A}-w^{B}\right) r^{t}$. This, in turn, implies that $z=\left[w^{A}\left(w^{A}-w^{B}\right) x r^{t}-w^{B}\left(x w^{A}+(1-x) w^{B}\right)\left(r^{s}-r^{t}\right)\right] /$ $\left[w^{B}\left(w^{A}-w^{B}\right)(1-x)\left(r^{s}-r^{t}\right)\right]$. Furthermore, in period 1 lenders are only willing to offer a contract of the form $\left(p^{d}=\mathrm{A}, r^{d}=r^{t}\right)$ if the total fraction of borrowers who choose project $\mathrm{A}$ ensures that they are at least indifferent between offering this contract and offering the contract $\left(p^{d}=\mathrm{B}, r^{d}=r^{s}\right)$. This requires that the following condition holds: $\left[w^{A}(x+(1-x) z)+\right.$ $\left.w^{B}(1-x)(1-z)\right] r^{t} \geq w^{B} r^{s}$. Given the repayment behavior of selfish borrowers in period 1 this condition can only be satisfied if the initial fraction of trustworthy borrowers is not too low: $x$ $\geq\left(w^{B}\right)^{2} r^{s}\left(r^{s}-r^{t}\right) / w^{A}\left(w^{A}-w^{B}\right)\left(r^{t}\right)^{2}$. 


\section{References}

Ai, Chunrong, and Edward Norton, 2003, Interaction Terms in Logit and Probit Models, Economics Letters 80 1,123-129

Ang, James S., and Thomas Schwarz, 1985, Risk Aversion and Information Structure: An Experimental Study of Price Variability in the Securities Markets, Journal of Finance $403,825-44$.

Baker, George, Robert Gibbions, and Kevin J. Murphy, 1994, Subjective Performance Measures in Optimal Incentive Contracts, Quarterly Journal of Economics, 1096 , 1125-1156.

Bellemare, Charles, and Sabine Kröger, 2007, On Representative Social Capital, European Economic Review 51 1, 183-202.

Bellemare, C., Kröger, S, van Soest, A., 2008, Measuring Inequity Aversion in a Heterogeneous Population using Experimental Decisions and Subjective Probabilities, Econometrica 76 4, 815-839.

Berger, Allen N., and Gregory F. Udell, 1995, Relationship Lending and Lines of Credit in Small Firm Finance, Journal of Business 68 3, 351-81.

Bolton, Gary, and Axel Ockenfels, 2000, ERC - A Theory of Equity, Reciprocity and Competition", American Economic Review 90 1, 166-193.

Boot, Arnoud W. A., 2000, Relationship Banking: What Do We Know?, Journal of Financial Intermediation 9 1, 7-25.

Boot, Arnoud W. A., and Anjan V. Thakor, 2000, Can Relationship Banking Survive Competition?, Journal of Finance 55 2, 679-713.

Brown, Martin, Armin Falk, and Ernst Fehr, 2004, Relational Contracts and the Nature of Market Interactions, Econometrica 72 3, 747-80.

Brown, Martin, and Christian Zehnder, 2007, Credit Reporting, Relationship Banking, and Loan Repayment, Journal of Money, Credit and Banking 39 8, 1883-1918.

Burrell, O. K., 1951, Possibility of an Experimental Approach to Investment Studies, The Journal of Finance 6 2, 211-219.

Camerer, Colin, 2003. Behavioral Game Theory: Experiments in Strategic Interaction (Princeton University Press, Princeton).

Charness, Gary, and Matthew Rabin, 2002, Understanding Social Preferences with Simple Tests, Quarterly Journal of Economics 117 3, 817-69.

Copeland, Thomas E., and Daniel Friedman, 1987, The Effect of Sequential Information Arrival on Asset Prices: An Experimental Study, Journal of Finance 42 3, 763-97.

Copeland, Thomas E., and Daniel Friedman, 1991, Partial Revelation of Information in Experimental Asset Markets, Journal of Finance 46 1, 265-95.

Degryse, Hans, and Steven Ongena, 2005, Distance, Lending Relationships, and Competition, Journal of Finance 60 1, 231-66.

Diamond, Douglas W., 1989, Reputation Acquisition in Debt Markets, Journal of Political Economy 97 4, 828-62.

Djankov, Simeon, Caralee McLiesh, and Andrei Shleifer, 2007, Private Credit in 129 Countries, Journal of Financial Economics 84 2, 299-329. 
Djankov, Simeon, Oliver Hart, Caralee McLiesh, and Andrei Shleifer, 2008, Debt Enforcement around the World, Journal of Political Economy 116 6, 1105-1149.

Dufwenberg, Martin, and Georg Kirchsteiger, 2004, A Theory of Sequential Reciprocity, Games and Economic Behavior 47 2, 268-98.

Falk, Armin, and Urs Fischbacher, 2006, A Theory of Reciprocity, Games and Economic Behavior 54 2, 293-315.

Fehr, Ernst, Urs Fischbacher, Jürgen Schupp, Bernhard von Rosenbladt, and Gert Wagner, 2002, A Nation-Wide Laboratory: Examining Trust and Trustworthiness by Integrating Behavioral Experiment into Representative Surveys, Schmollers Jahrbuch: Zeitschrift fur Wirtschafts- und Sozialwissenschaften/Journal of Applied Social Science Studies 122 4, 519-42.

Fehr, Ernst, and Simon Gächter, 2000, Fairness and Retaliation: The Economics of Reciprocity, Journal of Economic Perspectives 14 3, 159-81.

Fehr, Ernst, and Klaus M. Schmidt, 1999, A Theory of Fairness, Competition, and Cooperation, Quarterly Journal of Economics 114 3, 817-68.

Fischbacher, Urs, 2007, Z-Tree: Zurich Toolbox for Ready-Made Economic Experiments, Experimental Economics 10 2, 171-78.

Fudenberg, Drew, and Eric Maskin, 1986, The Folk Theorem in Repeated Games with Discounting or with Incomplete Information, Econometrica 54 3, 533-54.

Gneezy, Uri, Arie Kapteyn, and Jan Potters, 2003, Evaluation Periods and Asset Prices in a Market Experiment, Journal of Finance 58 2, 821-37.

Greiner, Ben, 2004, An Online Recruiting System for Economic Experiments, in Kurt Kremer, Volker Macho (Eds.): Forschung und wissenschaftliches Rechnen 2003. GWDG Bericht 63, Göttingen: Ges. für Wiss. Datenverarbeitung, 79-93.

Haigh, Michael S., and John A. List, 2005, Do Professional Traders Exhibit Myopic Loss Aversion? An Experimental Analysis, Journal of Finance 60 1, 523-34.

Haruvy, Ernan, and Charles N. Noussair, 2006, The Effect of Short Selling on Bubbles and Crashes in Experimental Spot Asset Markets, Journal of Finance 61 3, 1119-57.

Jaffee, Dwight M., and Thomas Russell, 1976, Imperfect Information, Uncertainty, and Credit Rationing, Quarterly Journal of Economics 90 4, 651-66.

Jappelli, Tullio, and Marco Pagano, 2002, Information Sharing, Lending and Defaults: CrossCountry Evidence, Journal of Banking and Finance 26 10, 2017-45.

Jappelli, Tullio, Marco Pagano, and Magda Bianco, 2005, Courts and Banks: Effects of Judicial Enforcement on Credit Markets, Journal of Money, Credit, and Banking 372 , 223-44.

Kluger, Brian D., and Steve B. Wyatt, 2004, Are Judgment Errors Reflected in Market Prices and Allocations? Experimental Evidence Based on the Monty Hall Problem, Journal of Finance 59 3, 969-97.

Kreps, David M., Paul R. Milgrom, John Roberts, and Robert Wilson, 1982, Rational Cooperation in the Finitely Repeated Prisoners' Dilemma, Journal of Economic Theory 27 2, 245-52.

Lamoureux, Christopher G., and Charles R. Schnitzlein, 1997, When It's Not the Only Game in Town: The Effect of Bilateral Search on the Quality of a Dealer Market, Journal of Finance 52 2, 683-712. 
LaPorta, Rafael, and Florencio Lopez de-Silanes, 1998, Capital Markets and Legal Institutions, in Shahid Burki and Guillermo Perry (Eds.): Beyond the Washington Consensus: Institutions Matter, The World Bank, Washington D.C.

LaPorta, Rafael, Florencio Lopez de-Silanes, Andrei Shleifer, and Robert W. Vishny, 1997, Legal Determinats of External Finance, Journal of Finance 52 3, 1131-50.

Lerner, Josh, and Antoinette Schoar, 2005, Does Legal Enforcement Affect Financial Transactions? The Contractual Channel in Private Equity, The Quarterly Journal of Economics, 120 1, 223-246.

O'Brien, John, and Sanjay Srivastava, 1991, Dynamic Stock Markets with Multiple Assets: An Experimental Analysis, Journal of Finance 46 5, 1811-38.

Ongena, Steven, and David C. Smith, 2000, What Determines the Number of Bank Relationships? Cross-Country Evidence, Journal of Financial Intermediation 9 1, 2656.

Ongena, Steven, and David C. Smith, 2001, The Duration of Bank Relationships, Journal of Financial Economics 61 3, 449-75.

Pagano, Marco, and Tullio Jappelli, 1993, Information Sharing in Credit Markets, Journal of Finance 48 5, 1693-1718.

Petersen, Mitchell A., and Raghuram G. Rajan, 1994, The Benefits of Lending Relationships: Evidence from Small Business Data, Journal of Finance 49 1, 3-37.

Rabin, Matthew, 1993, Incorporating Fairness into Game Theory and Economics, American Economic Review 83 5, 1281-1302.

Rajan, Raghuram G., and Luigi Zingales, 1995, What Do We Know about Capital Structure? Some Evidence from International Data, Journal of Finance 50 5, 1421-60.

Schnitzlein, Charles R., 1996, Call and Continuous Trading Mechanisms under Asymmetric Information: An Experimental Investigation, Journal of Finance 51 2, 613-36.

Sobel, Joel, 1985, A Theory of Credibility, Review of Economic Studies 52 4, 557-73.

Sobel, Joel, 2005, Interdependent Preferences and Reciprocity, Journal of Economic Literature 93 2, 392-436.

Sobel, Joel, 2006, For Better of Forever: Formal versus Informal Enforcement, Journal of Labor Economics, 24 2, 271-297.

Stiglitz, Joseph E., and Andrew Weiss, 1981, Credit Rationing in Markets with Imperfect Information, American Economic Review 71 3, 393-410.

Vercammen, James A., 1995, Credit Bureau Policy and Sustainable Reputation Effects in Credit Markets, Economica 62 248, 461-78. 


\section{Tables}

\section{Table I: Characteristics of Projects}

The table displays the characteristics of the two projects available to borrowers. Project A has a high probability of success and maximizes the expected returns on investment. Project B is an inefficient high-risk project. Due to limited liability and wealth constraints Project B can be attractive to borrowers when they plan or have to make a positive repayment in case of project success.

\begin{tabular}{lcc} 
& Project A & Project B \\
\hline Required investment $(i)$ & 32 & 32 \\
Probability of success $\left(w^{p}\right)$ & 0.8 & 0.3 \\
Return in case of success $\left(R^{p}\right)$ & 100 & 200 \\
Return in case of failure & 0 & 0 \\
Expected return $\left(\mathrm{E}[R \mid p]=w^{p} R^{p}\right)$ & 80 & 60 \\
\hline
\end{tabular}


Table II: Conditional Contract Renewals in the RC

The table reports regression estimates using individual data on credit contract renewals in the RC. All columns report probit estimates for the probability that a borrower receives a private offer from the same lender in the next period. The dependent variable in all regressions is an indicator variable which takes on the value 1 if the borrower received a private offer from the same lender in the next period and 0 otherwise. In regression [1] we regress the dependent variable on the repayment level in the current period (Column ME [1] shows the corresponding marginal effects). In regression [2] we add the average repayment in all past periods and the number of previous interactions to the set of explanatory variables (Column ME [2] shows the corresponding marginal effects). In regression [3] we regress the dependent variable on an indicator variable that takes on the value 1 if the borrower has made a positive repayment in the current period (Column ME [3] shows the corresponding marginal effects). In regression [4] we add the percentage of positive repayments in previous interactions and the number of previous interactions to the regression (Column ME [4] shows the corresponding marginal effects).

Dependent variable

Private offer of the same lender in the next period

\begin{tabular}{|c|c|c|c|c|c|c|c|c|}
\hline & [1] & ME [1] & [2] & ME [2] & [3] & ME [3] & [4] & ME [4] \\
\hline \multirow[t]{2}{*}{ Current repayment } & $0.028 * * *$ & $0.011^{* * *}$ & $0.028 * * *$ & $0.011 * * *$ & & & & \\
\hline & {$[0.002]$} & {$[0.001]$} & {$[0.002]$} & {$[0.001]$} & & & & \\
\hline \multirow[t]{2}{*}{ Previous repayments } & & & $0.011 * *$ & $0.004 * *$ & & & & \\
\hline & & & {$[0.005]$} & {$[0.002]$} & & & & \\
\hline \multirow[t]{2}{*}{ Positive current repayment } & & & & & $1.318 * * *$ & $0.477 * * *$ & $1.346^{* * *}$ & $0.482 * * *$ \\
\hline & & & & & {$[0.056]$} & [0.014] & [0.112] & {$[0.027]$} \\
\hline \multirow[t]{2}{*}{ Positive previous repayments } & & & & & & & $0.689 * * *$ & $0.271 * * *$ \\
\hline & & & & & & & [0.239] & {$[0.094]$} \\
\hline \multirow[t]{2}{*}{ Previous interactions } & & & $0.090 * * *$ & $0.035 * * *$ & & & $0.077 * * *$ & $0.031 * * *$ \\
\hline & & & {$[0.023]$} & {$[0.009]$} & & & {$[0.020]$} & {$[0.008]$} \\
\hline \multirow[t]{2}{*}{ Constant } & $-0.949 * * *$ & & $-1.581 * * *$ & & $-0.911 * * *$ & & $-1.555^{* * *}$ & \\
\hline & {$[0.115]$} & & {$[0.154]$} & & {$[0.119]$} & & {$[0.159]$} & \\
\hline Observations & 565 & 565 & 565 & 565 & 565 & 565 & 565 & 565 \\
\hline
\end{tabular}




\section{Table III: Expected Borrower Profits per Project in the RC and TPC}

This table shows how much borrowers can gain in terms of expected short term profit if they choose project B although the lender asked for project $\mathrm{A}$. The table displays expected period profits of borrowers for each possible project choice conditional on the total number of interactions with the current lender. The numbers in brackets display the number of observations. In the TPC it is simple to calculate the expected profits. Since the desired repayment is enforceable, we take all concluded contracts in which the lender desired project $\mathrm{A}$ and calculate the expected profits as follows: Expected profit = Probability of success $\mathrm{x}$ (Project return - Desired repayment). In the RC, in contrast, the desired repayment is not binding and the borrower can repay as much as he wants. In this case we take all accepted contracts in which the lender desired project A and the borrower successfully completed a project (either A or B). We calculate the expected profits as follows: Expected profit $=$ Probability of success $\mathrm{x}$ (Project return - Observed repayment). We need to restrict the database to contracts with successful projects because the intended repayment in case of project failure is not observable. This does not bias the results, because project success is determined randomly.

\begin{tabular}{ccccccc}
\hline \hline & \multicolumn{3}{c}{ RC } & \multicolumn{3}{c}{ TPC } \\
Interactions & Project A & Project B & Project A & Project B \\
\hline $1-3$ & 54 & & 50 & 21 & 38 \\
& & $(158)$ & & & $(173)$ & \\
$4-10$ & 43 & & 46 & 22 & & 38 \\
& & $(177)$ & & & $(173)$ & \\
$11-20$ & 41 & & 45 & 27 & & 40 \\
& & $(154)$ & & & & $(176)$ \\
\hline
\end{tabular}


The table reports regression estimates using individual data on credit contract renewals in the RC and the TPC. All columns report probit estimates for the probability that a

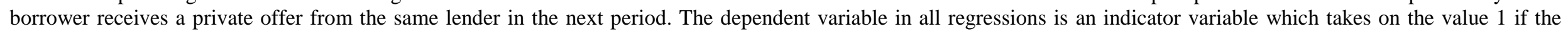
borrower received a private offer from the same lender in the next period and 0 otherwise. In regression [1] we regress the dependent variable on the repayment level in the current period, a dummy variable for the TPC and the interaction terms of these two variables (Column ME [1] shows the corresponding marginal effects). In regression [2] we add the average repayment level in all past periods, the number of previous interactions and the corresponding interaction terms with the TPC dummy to the set of explanatory variables (Column ME [2] shows the corresponding marginal effects). In regressions [3] and [4] we replace current repayment level and average past repayment level with an indicator for a positive repayment and the percentage of positive repayments in previous interactions (Column ME [3] and ME [4] show the corresponding marginal effects).

Dependent variable

Private offer of the same lender in the next period

Current repayment

Current repayment x TPC

$0.028 * * *$
ME[1]

[0.002]

$0.011 * * *$

[2]

[0.001]

$0.028 * * *$

ME[2]

$0.011 * * *$ $[3]$

$\mathrm{ME}[3]$

[4]

ME[4]

$-0.021 * * *$

$-0.005 * * * 1$

$-0.021 * * *$

[0.001]

[0.002]

[0.001]

[0.003]

$-0.005^{* * * 1}$

Previous repayments

$0.011^{* *}$

[0.001]

[0.005]

$0.004 * *$

$-0.006$

[0.002]

Previous repayments $\mathrm{x}$ TPC

[0.005]

$-0.001^{1}$

Positive current repayment

Positive current repayment $\mathrm{x}$ TPC

Positive previous repayments

Positive previous repayments x TPC

Previous interactions

$0.090 * * * \quad 0.034 * * *$

[0.021] [0.008]

Previous interactions x TPC

$0.052 * *$

$[0.026] \quad[0.008]$

TPC

$\begin{array}{cc}0.222 & 0.084 \\ {[0.157]} & {[0.060]}\end{array}$

Constant

$-0.949 * *$

[0.060]

$0.168 \quad 0.063$

****

[0.164]

$-1.581 * * *$

[0.145]

[0.061]

1239

1239

$0.454 * * *$

$1.346 * * *$

$0.454 * * *$

$-0.284 * * * \quad-0.132 * * * 1 \quad-0.366^{* *} \quad-0.147 * * * 1$

[0.078]

[0.039]

$[0.143]$

[0.044]

$0.689 * * * \quad 0.255^{* * * *}$

[0.225] [0.084]

$0.143 \quad 0.029^{1}$

[0.309] [0.084]

$0.077 * * * \quad 0.029 * * *$

[0.019] [0.007]

$\begin{array}{ll}0.029 & 0.006^{1}\end{array}$

$\begin{array}{cc}{[0.027]} & {[0.008]} \\ -0.211 & -0.078\end{array}$

[0.169] [0.063]

[0.154]

$-0.911 * * *$

[0.058]

$-1.555^{* * *}$

[0.150]

1239

${ }^{1}$ Since the interaction effect does not correspond to the marginal effect of the interaction term in non-linear estimations, we used the procedure recommended by Ai and Norton (2003) to estimate the correct interaction effects. 


\section{Figures}

Figure I: Realized Fraction of Available Number of Contracts over Time

The figure displays the development of the realized fraction of the available number of contracts over the 20 periods of the experiment in the OC, the RC and the TPC.

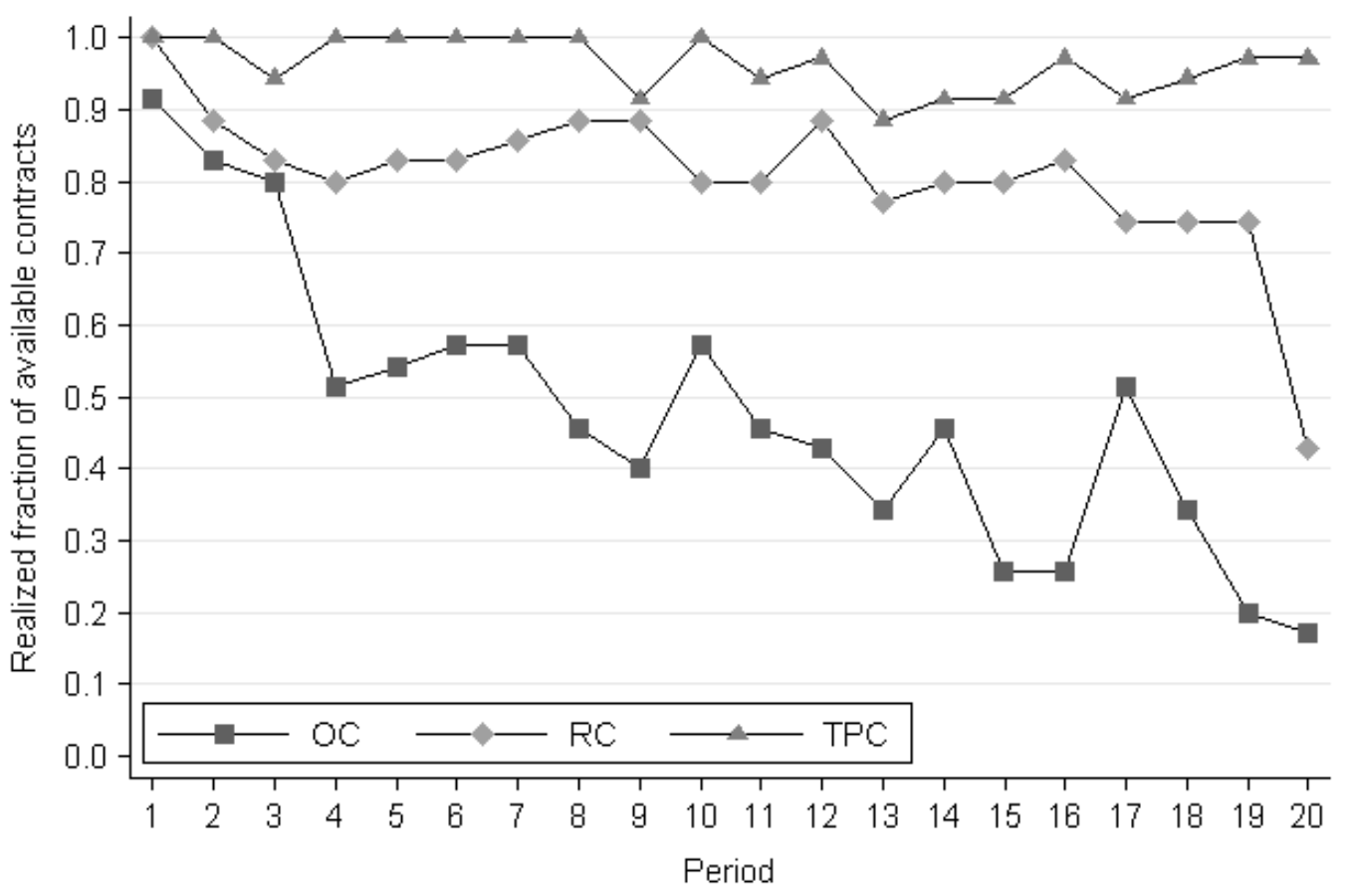


Figure II: Average Repayments and Fraction of Ex Ante Profitable Contracts in the OC

Panel A: The figure displays the development of average repayments over time in the OC. The grey line represents the lenders' outside option (endowment storing) of 32.

Panel B: The figure shows the fraction of concluded contracts that were efficient from an ex ante perspective. There are two cases in which the contract is profitable to the lender from an ex ante perspective. The first case is that the borrower chooses project $\mathrm{A}$ and repays at least 40 in case of success (Expected Profit $=0.8 \times 40=32$ ). The second case is that the borrower chooses project B and repays at least 107 (Expected Profit $=0.3 \times 107 \approx 32$ ). In both these cases the expected profit for the lender is at least 32. In contracts with project failures we do not observe how much the borrower would have repaid if the project had been a success. Accordingly, we only use contracts with successful projects as the database for this figure. However, since project success is randomly determined, this does not bias the results.

Figure III: Average repayments in the $\mathrm{OC}$ and $\mathrm{RC}$ and Individual Repayments in the RC

Panel A: The figure displays the development of average repayments after project success in the OC and the RC. Panel B: The figure shows the frequency of positive repayments in periods 1-18 and periods 19-20 of the experiment using individual data from the RC. Each point in the figure represents one or several identical individuals. The size of the point indicates the number of observations.
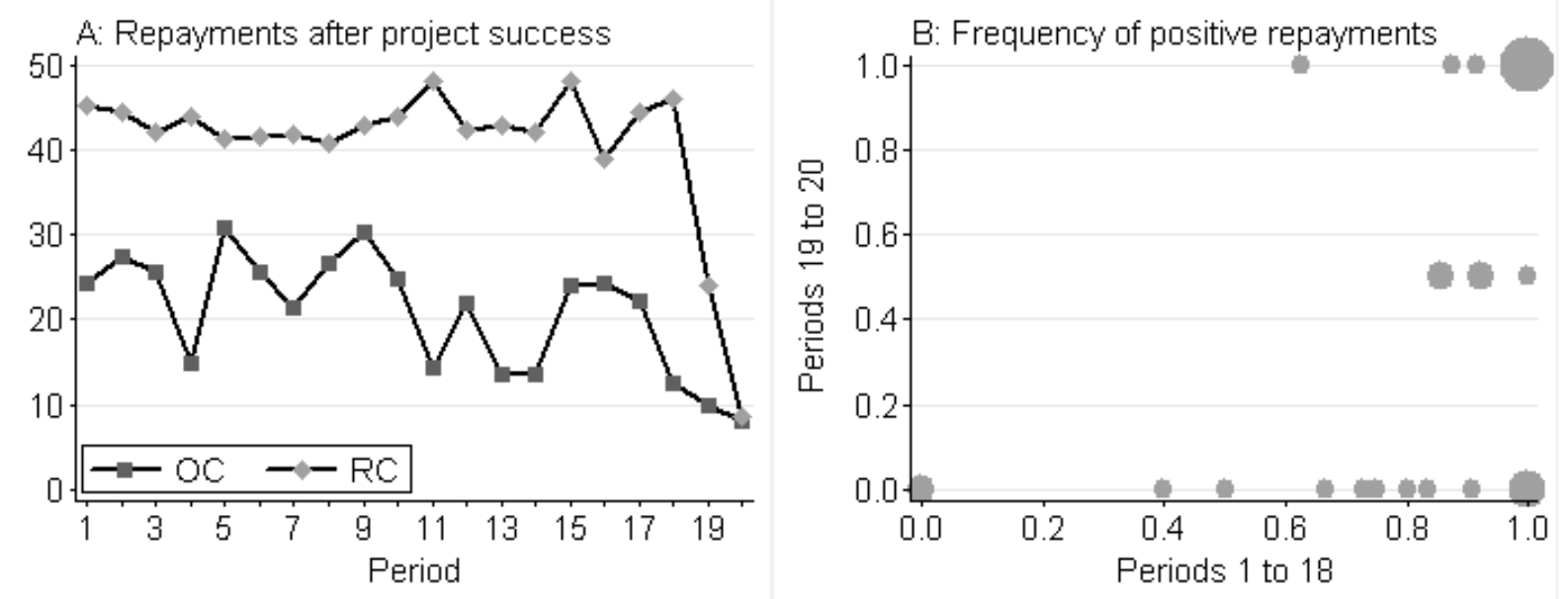
Figure IV: Cumulative Frequency of Interactions of the Same Pair in the OC and RC

The figure displays the cumulative frequency of trades which take place within pairs who interact a certain number of times with each other.

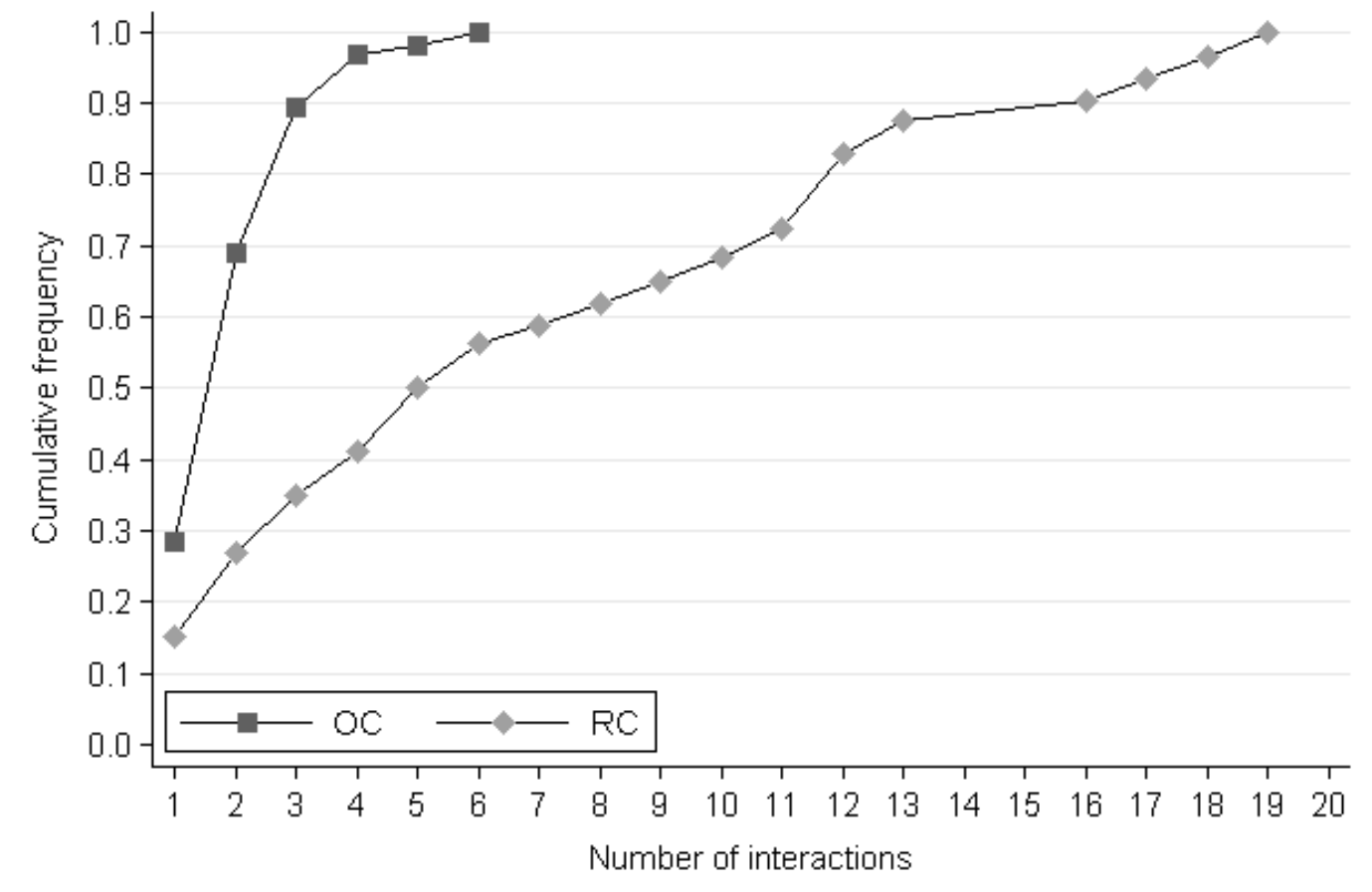


Figure V: Project Choice and Repayments Conditional on the Number of Interactions of a Pair

Panel A: The figure displays the frequency with which project $\mathrm{A}$ is chosen in concluded contracts conditional on the number of interactions of the same pair in the RC.

Panel B: The figure shows the average repayment after project success conditional on the number of interactions of the same pair in the RC.
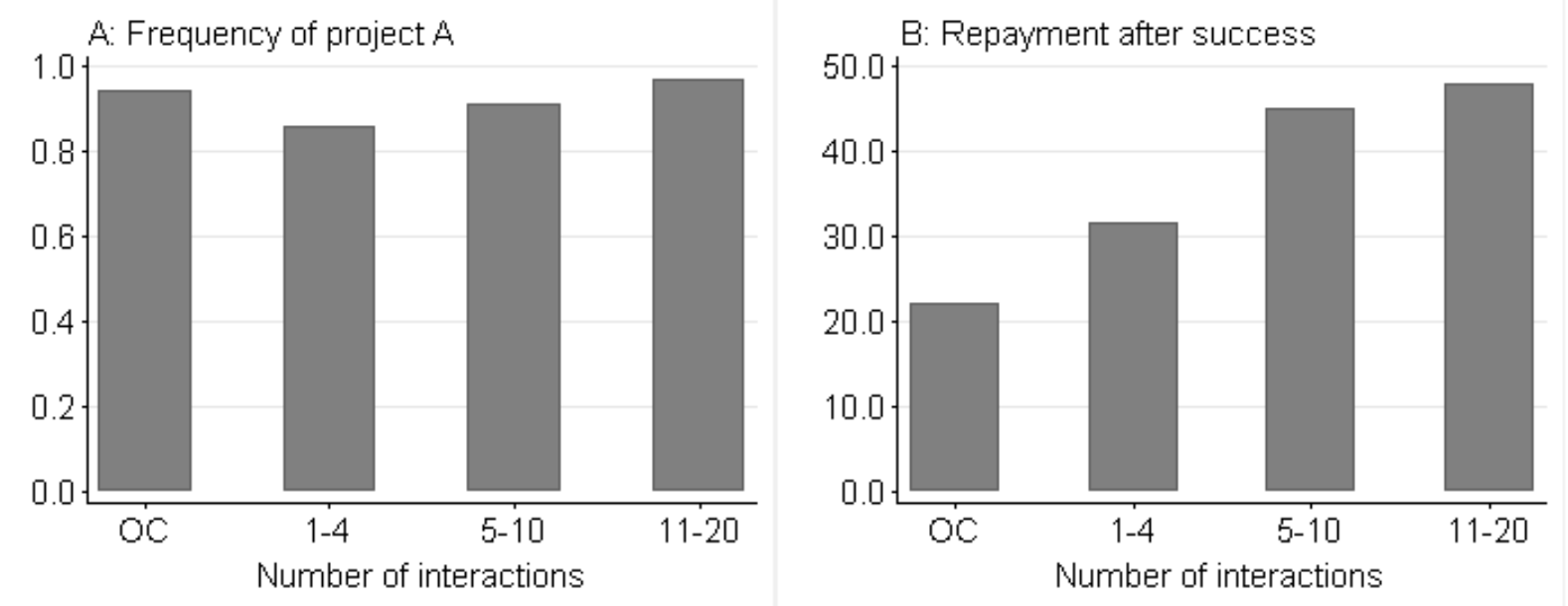
Figure VI: Cumulative Frequency of Interactions of the Same Pair in the RC and TPC

The figure displays the cumulative frequency of trades which take place within pairs who interact a certain number of times with each other.

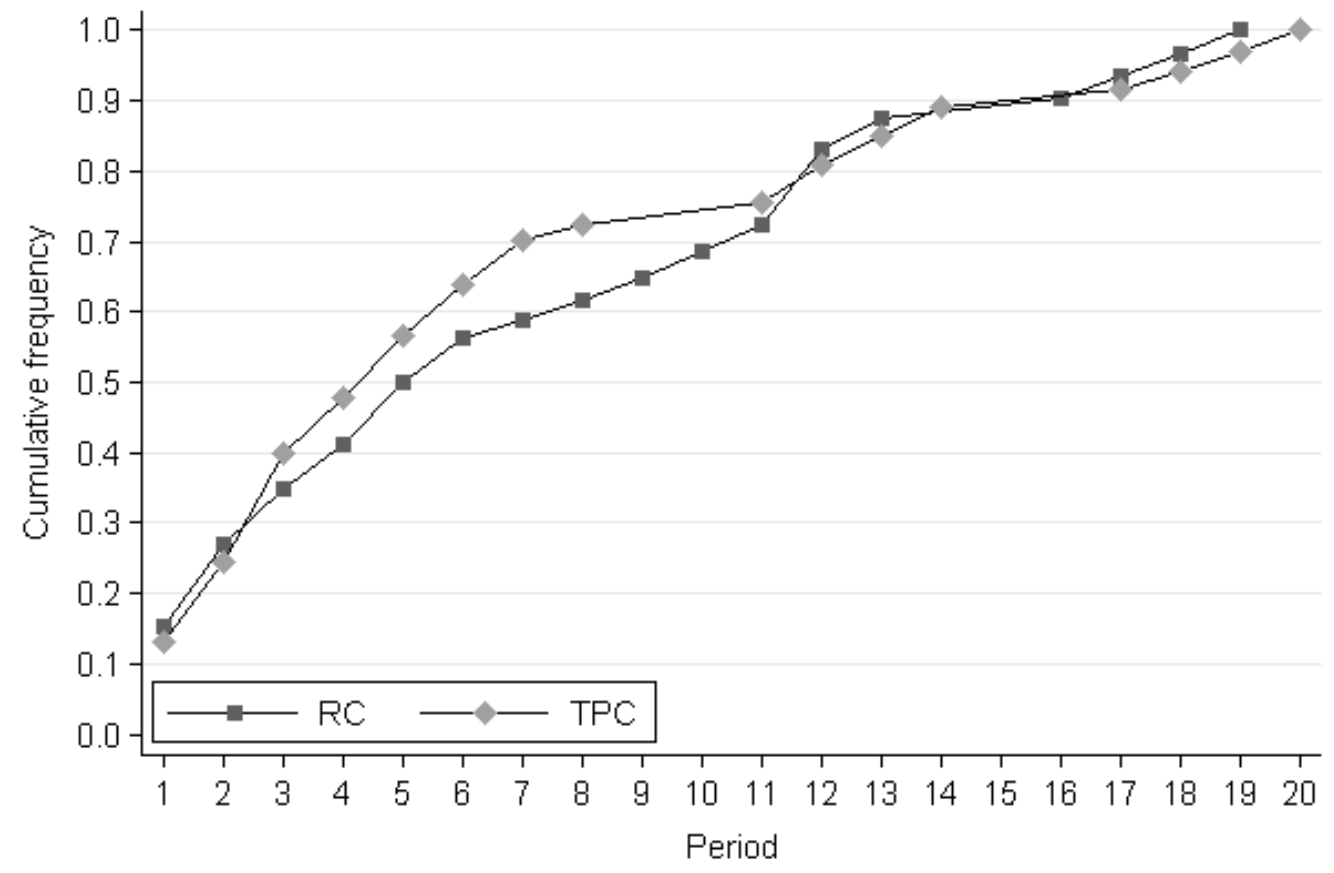


Figure VII: Project Choice and Repayments Conditional on the Number of Interactions of a Pair

Panel A: The figure displays the frequency with which project $\mathrm{A}$ is chosen in concluded contracts conditional on the number of interactions of the same pair in the TPC.

Panel B: The figure shows the average repayment conditional on the number of interactions of the same pair in the TPC.
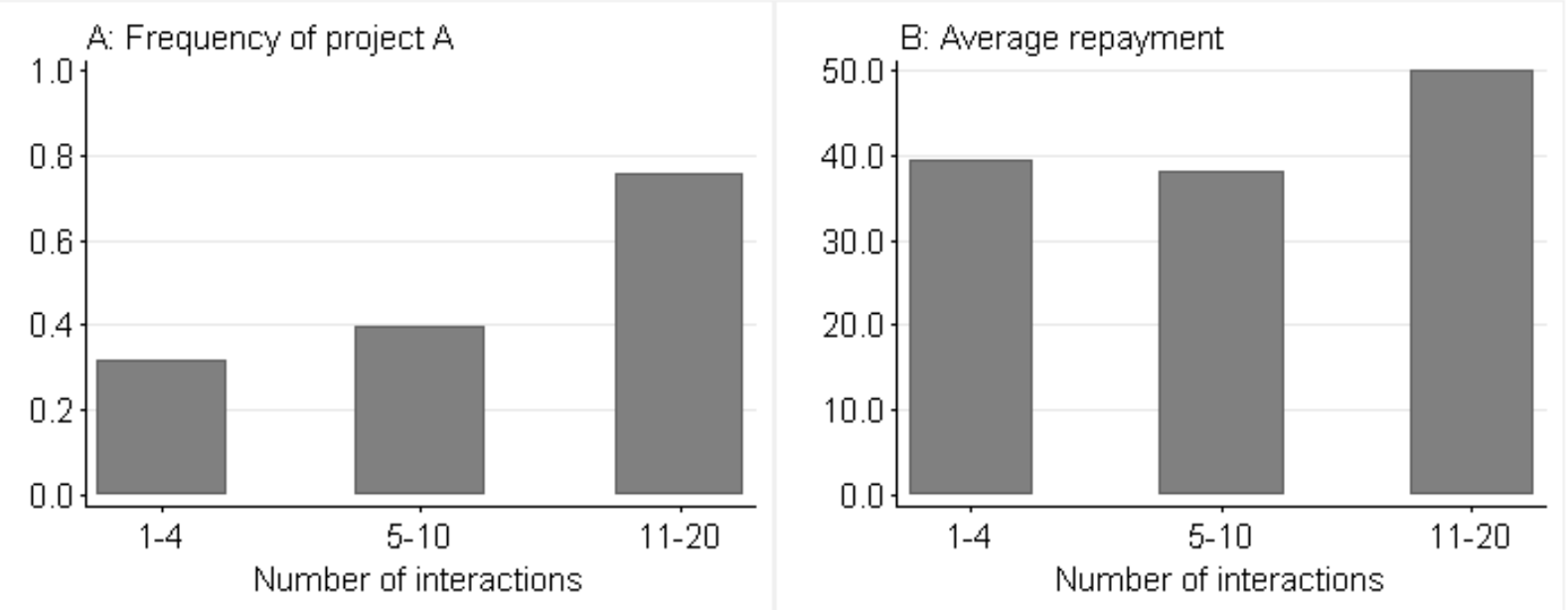